\title{
A taxonomic synopsis of Cypella (Iridaceae) in Brazil
}

\author{
Lilian Eggers ${ }^{1,2 *}$ (D), Rafaella Marchioretto ${ }^{1}$ (D), Tatiana T. Souza-Chies ${ }^{1,2}$ (i) , Tamara Pastori ${ }^{2}$ (i) \\ and Olivier Chauveau ${ }^{2,3}$ (D)
}

Received: May 10, 2019

Accepted: August 6, 2019

\section{ABSTRACT}

A taxonomic synopsis of Cypella (Iridaceae) in Brazil is presented with recognition of 16 species, two of them represented by two subspecies. An identification key to the taxa is provided and species are described and illustrated. New synonyms are indicated, and eight lectotypes, two epitypes and one neotype are designated. Results include distribution, habitat, phenology, conservation status, notes and examined specimens of all taxa, as well as comments on dubious and misused names. The resulting framework revealed that most of the Brazilian species of Cypella occur in the state of Rio Grande do Sul and in the Pampa Biome, although Río de la Plata grasslands (RPG) is the most species-rich biogeographic unit of the genus.

Keywords: Campos, Cypella, floristics, Iridaceae, Pampa, Rio de la Plata Grasslands, taxonomy, Tigridieae, typification

\section{Introduction}

Species are broadly considered fundamental units of conservation and taxonomic studies are therefore critical for biodiversity analyses (Freudenstein et al. 2017; Wilson 2017; Coates et al. 2018). However, speciation events are neither instantaneous nor synchronized over evolutionary time and description of species characteristics as well as accurate assessment of species boundaries remain two major challenges to understand biological diversity (DinizFilho et al. 2013; Pimm et al. 2014; Coates et al. 2018). Current species richness and geographic distribution of Iridaceae in South America are still difficult to estimate even though floras and checklists provide valuable but incomplete information (e.g. Ravenna 1968; 2003; Roitman et al. 2008). Recent and massive effort was conducted to assemble data for the Brazilian flora and biodiversity information was the focus of this major initiative headed by the Jardim Botânico do Rio de Janeiro and called Lista de Espécies da Flora do Brasil (Forzza et al. 2010; BFG 2015). The list of Iridaceae reported in this project encompasses 160 species distributed among 18 genera (Eggers et al. 2010). Subsequently, knowledge on systematics and taxonomy of Iridaceae was expanded through increasing collections, phylogenetic approaches (Chauveau et al. 2011; 2012; Lovo et al. 2012; Alves et al. 2014; Inácio et al. 2017; Stiehl-Alves et al. 2017); multivariate statistical treatments (Pastori et al. 2018); and various new species publications (Lovo \& MelloSilva 2011; Deble et al. 2012c; 2015a; b; Aita et al. 2013; Chauveau et al. 2014; Gil et al. 2014; Oliveira et al. 2016; Inácio et al. 2018). Despite considerable advances, various genera still need to be broadly and thoroughly explored to assess their taxonomic delimitation and infrageneric classification (Chauveau et al. 2012; Pastori et al. 2018).

Among Brazilian Iridaceae, Cypella is one of the most species-rich genus of the tribe Tigridieae (Iridoideae, Iridaceae) and is mainly found in the biogeographic unit of Rio de la Plata Grasslands (RPG), where more than 30 species and subspecies are currently reported (Barker 2019). Species of Cypella colonize various grassland formations, which range from very dry and stony to flooded grasslands

1 Departamento de Botânica, Universidade Federal do Rio Grande do Sul, 91501-970, Porto Alegre, RS, Brazil 
mostly distributed in Pampas and Campos eco-regions but also in adjacent areas such as the subtropical Highland Grasslands (Iganci et al. 2011). RPG is considered as the centre of diversity of the genus (Chauveau et al. 2014) by the proportion of inhabiting species and newly described taxa (Pastori et al. 2018). In 2010, only 14 species of Cypella were listed for Brazil (Eggers 2010) but ten taxa were discovered during the last decade in Southern Brazil (Deble et al. 2012c; 2015a; b; Chauveau et al. 2014) and phylogenetic studies revealed that at least one of the previously listed species was only distantly related to the genus (Chauveau et al. 2012). In this context, the species delimitation framework presented last year for C. pusilla (Pastori et al. 2018) and the recent studies carried out for the Brazilian Flora 2020 project (Flora do Brasil 2020 em construção 2019) revealed that a revision of the taxonomic entities currently included in Cypella and a complete treatment of the Brazilian species are mandatory and should provide efficient tools for species recognition and identification. To contribute to this task, a synopsis of the species and subspecies of Cypella from Brazil is here presented, with concise descriptions, new synonyms, typification, taxonomic key, iconography, and data on distribution, habitat, phenology, conservation status and comments.

\section{Materials and methods}

Species synopsis were generated consulting protologues, posterior descriptions from literature and by analysis of live specimens and herbarium material from collections deposited at the herbaria B, BA, BAA, BAB, CORD, CTES, G, HAS, HBR, ICN, K, LP, MBM, MPUC, MVFA, MVJB, MVM, NY, P, PACA, R, RB, SI, SMDB, UEC (acronyms according to NYBG 2019). Digital images from herbaria BM, CGMS, G, MO, NY, S, UPCB, US were also examined. Historically, material from the Herbarium Ravenna is not available for consultation (Gil 2012; Deble \& Alves 2017a; Lovo et al. 2018), and when necessary new types are here designated. Plant features for the descriptions were selected by their importance for the recognition of the set of species and measures of morphological structures include the most common variation range, excluding outliers. Coloration was detailed based on flowers observed in field trips performed since 2003 and in plants cultivated from bulbs collected in the field and maintained at Universidade Federal do Rio Grande do Sul. The terminology used for the descriptions follows Goldblatt \& Manning (2008), with few modifications, and Beentje (2016).

Identification key was constructed mostly to attend determination at the field and/or with fresh flower material or detailed photograph record. Identification of flower colour is of primary importance to follow the dichotomic key here presented. Colour is strongly influenced by light intensity and photographs may confound colour definition, especially when yellow to orange limit is close. To avoid innacuracies, we emphasize that the yellow flowers of the dichotomic key include gold (RGB code $255,215,0$ ) and golden yellow (RGB 255, 223, 0) colours.

A detailed photographic record of diagnostic floral features was made to illustrate features or structures not shown or poorly shown for some species in preceding literature. Morphological illustration of gynoecium characteristics are firstly presented to enable better understanding of terminology and are exhibited for all species. The drawings were made based on living plants and digital images.

Iconography references were selected with the aim to include ancient and recent illustrations, and are presented in alphabetical order of authors. Distribution, habitat and phenology were based on literature revision, herbarium specimens, cultivated material and fieldwork observations. Biomes were defined according IBGE (2004) and vegetation types follow BFG (2015) for aquatic vegetation and anthropized areas, and Overbeck et al. (2007) and Andrade et al. (2019) for grasslands (s.l.). When relevant, grasslands were better characterized concerning substrate characteristics related to humidity or presence of stones. Conservation status was assessed for the species which did not present threatened categorization in the literature. For species with published category of threat, original classification was evaluated taking into account new information on collections or habitat. Analysis was performed according to IUCN Red List guidelines (IUCN 2017).

The examined material includes the analysed specimens from Brazil, and additional material from neighbouring countries (Argentina, Paraguay and Uruguay) where the species also occur. Additional specimens are provided to present the full known geographic distribution of the taxa, which enables, as well, the analysis of the conservation status of the species.

\section{Results and discussion}

\section{Taxonomic treatment}

Cypella Herb., Curtis's Botanical Magazine 53: t. 2637. 1826. Type: Cypella herbertii (Lindl.) Herb.

Bulbose herb, bulbs covered by brown to black tunics. Basal leaves few, ensiform to linear, sometimes narrowly elliptic, with projections to both sides of the leaf lamina, giving an appearance of pleated leaf. Floriferous stem terete, simple or branched. Synflorescences formed by rhipidia, frequently pedunculate, enclosed by green conspicuous bracts (usually called spathe valves), the lower valve usually smaller than the upper valve. Rhipidia one to two-flowered. Flowers yellow to orange, or white to pale blue, frequently with contrasting spots or streaks, generally exposed out of the spathe valves (sometimes, ovary remains enclosed). Tepals free, dissimilar, clawed to cuneate, outer tepals larger than inner tepals, generally concave proximally, then patent, reclinate or 
reflexed; inner tepals porrect to incurved, then reclinate, usually with area of glandular trichomes (elaiophores). Androecium with filaments free to basally connate; anthers basifixed, apically affixed to the opposite style arm; and frequently with conspicuous connective (Fig. 1A). Gynoecium with an undivided portion of style, then divided in three style arms, each bearing two adaxial style crests, one abaxial style crest and two transversal stigmatic replicatures (Figs. 1, 2, 3). Fruit capsule, obloid to obovoid. Seeds angular.

The total number of species included in Cypella is still dependent on conflicting interpretations of the genus circumscription and varies from 30 to 38 (Goldblatt \& Manning 2008; Ravenna 2009; Barker 2019). The most recent molecular studies show that members of several closely related genera (i.e. Calydorea, Herbertia, Kelissa and Onira) are nested within Cypella (Chauveau et al. 2012; Pastori et al. 2018). However, the current resolution of several nodes as well as the incongruences observed between the phylogenies obtained separately from plastid and nuclear DNA datasets do not provide a robust framework to conduct unambiguously a taxonomic revision of the genus circumscription. In this context, we consider that the synonymisation of Kelissa and Onira with Cypella, a decision that was not justified by Roitman \& Castillo (2007), is currently not supported by the molecular evidence and does not satisfy the principle of monophyly. Consequently, we follow provisionally the circumscription of the genus stated by Ravenna (2009), excluding species of Kelissa and Onira from Cypella, but also species of Phalocallis included in Cypella by Goldblatt \& Manning (2008) and Barker (2019) because the type species of Phalocallis (P. coelestis) is confidentially not closely related to the remaining species of Cypella (Chauveau et al. 2012). In such framework, eighteen taxa are recorded in Brazil, and species and subspecies are distributed in the states of Mato Grosso do Sul, Minas Gerais, São Paulo, Paraná, Santa Catarina and Rio Grande do Sul.

\section{Key to species and subspecies of Brazilian Cypella}

1. Flowers yellow to orange

2. Flowers yellow

3. Rhipidia sessile to subsessile; synflorescence fasciculiform, subtended by a bract up to $5 \mathrm{~cm}$ long...... .C. pusilla

3'. Rhipidia conspicuously pedunculate, synflorescence terminal

4. Filaments filiform

5. Plants from lotic ecosystems, associated with rivers, creeks or streams

6. Leaves 1.1 to $3.2 \mathrm{~cm}$ wide; adaxial crests 2 to $4 \mathrm{~mm}$ long; pollen ochraceous; plants from riversides and river islets C. aquatilis

6'. Leaves 0.4 to $0.7 \mathrm{~cm}$ wide; adaxial crests 5.9 to $6.8 \mathrm{~mm}$ long; pollen yellow; plants from narrow and stony grassland streams..... C. rivularis

5'. Plants from bogs or flooded areas, grasslands or stony environments, not associated with rivers, creeks or streams 7. Filaments less than $4 \mathrm{~mm}$ long; adaxial crests up to $3.5 \mathrm{~mm}$ long; style arms red-brown distally. Plants from bogs and damp grasslands C. crenata 7'. Filaments more than $5.9 \mathrm{~mm}$ long; adaxial crests more than $4.5 \mathrm{~mm}$ long; style arms yellow, not red-brown distally 8. Outer tepals distinctly clawed, filaments 8.4 to $10.5 \mathrm{~mm}$ long; anthers 8 to $9.5 \mathrm{~mm}$ long. Plants from moist soils... C. charruana

8'. Outer tepals pandurate, not clawed, filaments 5.9 to $6.5 \mathrm{~mm}$ long; anthers 6.5 to $7.8 \mathrm{~mm}$ long. Plants from stony and rocky environments ..... C. ravenniana

4'. Filaments linear to triangular

9. Outer tepals entirely yellow, except for small dark red to red brown spots or streaks proximally; connective less than $1.2 \mathrm{~mm}$ wide

10. Style arms strongly divergent; adaxial crests longitudinally twisted at the middle portion 10'. Style arms mostly convergent; adaxial crests not longitudinally twisted at the middle portion .............. C. altouruguaya C. armosa 9'. Outer tepals densely covered by red spots proximally or with a brown central stripe; connective more than $2 \mathrm{~mm}$ wide 11. Outer tepals with a brown central stripe; connective dark purplish to red-brown, $3-3.6 \mathrm{~mm}$ wide; filaments 3 to 3.5 $\mathrm{mm}$ long, connate for 1.5 to 2.8 ; adaxial crests 0.5 to $0.8 \mathrm{~mm}$ long.. C. herbertii subsp. brevicristata 11'. Outer tepals densely covered by red spots proximally; connective dull yellow, $2-2.2 \mathrm{~mm}$ wide; filaments 4.5 to $5 \mathrm{~mm}$ long, connate for 0.5 to 0.8 ; adaxial crests 2.5 to $3.5 \mathrm{~mm}$ long .. C. guttata 2'. Flowers orange

12. Filaments 5.5 to $6.4 \mathrm{~mm}$ long; anthers 8 to $9 \mathrm{~mm}$ long; adaxial crests 6 to $7 \mathrm{~mm}$ long C. magnicristata

12'. Filaments up to $3.6 \mathrm{~mm}$ long; anthers up to $6.8 \mathrm{~mm}$ long; adaxial crests up to $5.3 \mathrm{~mm}$ long

13. Outer tepals with a conspicuous red brown or purple to purplish-red longitudinal central stripe

14. Filaments close to each other, basally connate; style arms distally red brown to dark purple; crests proximally stained 
red-brown to purple, adaxial crests 1.8 to $3 \mathrm{~mm}$ long; connective 1.5 to $1.8 \mathrm{~mm}$ wide; leaves large, about 2 to $2.5 \mathrm{~cm}$ in well developed plants

C. herbertii subsp. herbertii

14'. Filaments distant from each other, free; style arms entirely pale yellow to orange, not distally red brown to dark purple; crests entirely orange, adaxial crests 4 to $5 \mathrm{~mm}$ long; connective 0.7 to $1 \mathrm{~mm}$ wide; leaves never more than $1 \mathrm{~cm}$ wide C. amplimaculata

13'. Outer tepals without central stripe C. fucata

1'. Flowers white

15. Outer tepals distally reflexed; filaments 2 to $2.4 \mathrm{~mm}$ long; anthers 3.2 to $3.5 \mathrm{~mm}$ long C. luteogibbosa

15 '. Outer tepals distally slightly patent to reclinate; filaments up to $4.5 \mathrm{~mm}$ long; anthers up to $5 \mathrm{~mm}$ long

16. Flowers with conspicuous faint purple venation; outer and inner tepals superposed proximally, forming a concave center C. discolor

16. Flowers subtly tinged with yellow or blue, without visible venation; outer and inner tepals not superposed proximally, leaving gaps between them

17. Adaxial crests 3.7 to $4.5 \mathrm{~mm}$ long

C. hauthalii subsp. opalina

17. Adaxial crests obsolete to $1 \mathrm{~mm}$ long ..... C. hauthalii subsp. minuticristata

Cypella altouruguaya Chauveau \& L.Eggers, Phytotaxa 174(1): 26. 2014. Type: Brazil. Rio Grande do Sul: Trindade do Sul, 3 December 2011, T.B. Guimarães \& L. Dal Ri 6A (Holotype ICN!).

Figs. 2A, 4A.

Herb 39-70 cm high; basal leaves linear, $0.3-0.45 \mathrm{~cm}$ wide. Synflorescence of 2-4 pedunculate one-flowered rhipidia. Spathes lower valve $2.4-3.9 \mathrm{~cm}$ long, upper $4-6.3 \mathrm{~cm}$ long. Flowers yellow, $45-55 \mathrm{~mm}$ diameter. Outer tepals pandurate, proximally concave, distally reclinate to reflexed, with irregular red-brown spots proximally; inner tepals cuneate, assurgent proximally, then incurved and abruptly reclinate distally, proximally densely streaked with red-brown, distally bright yellow with light yellow central portion and dense oblong orange-yellow area of elaiophores, laterally bordered by red- brown streaks and apically spotted with red-brown. Filaments free, 3-3.5 $\mathrm{mm}$ long; anthers 6-7 $\mathrm{mm}$ long; connective whitish-yellow to yellow, $0.8-1.2 \mathrm{~mm}$ wide; pollen dark yellowgreen. Style whitish to yellow, 5-6 mm long; style arms bright yellow, 5-6.5 mm long, crests bright yellow. Adaxial crests, 2, erect, falcate inwards, 4-6 mm long, abaxial crest triangular, slightly lobed. Capsule obovoid-truncate.

Iconography: Chauveau et al. (2014).

Distribution, habitat, and phenology: Cypella altouruguaya occurs in the northern region of the state of Rio Grande do Sul, in the Atlantic Rainforest Biome. It grows in grasslands and in anthropized areas along rural roadsides, forming dense populations. Altitude records range from 592 to $615 \mathrm{~m}$ a.s.l. (Chauveau et al. 2014). Flowering and fruiting individuals were collected in August and December.
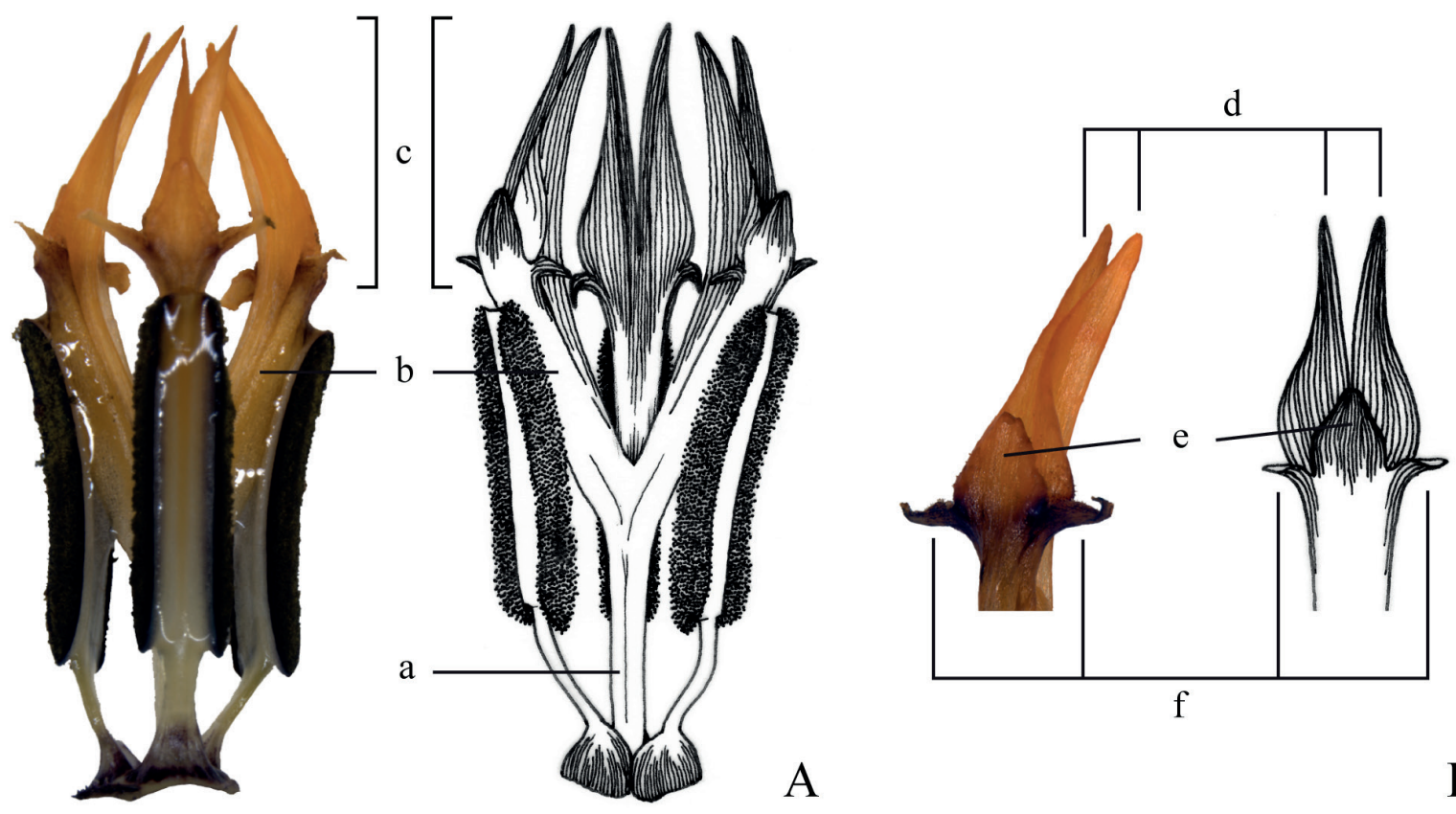

A

B

Figure 1. Androgynoecium (except ovary) of Cypella. A- Image and drawing of stamens, style and style crests, showing concrescent portion of style (a), style arms (b) and style crests (c). B - Image and drawing detail of the style crests showing adaxial crests (d), abaxial crest (e) and stigmatic replicatures (f). Drawings by R. Marchioretto. 
Conservation status: The species was considered as Critically Endangered - CR, B1a,b(iii) by Chauveau et al. (2014). There are no additional collections or other elements to justify change of categorization, thus conservation status is maintained.

Notes: Cypella altouruguaya is most similar to C. armosa, of which it can be distinguished by the appearance of the style arms (Fig. 2A vs. 2C). Style arms of C. altouruguaya are usually convergent ( $v s$. strongly divergent) and adaxial crests are not longitudinally twisted at the middle portion (vs. twisted).

Deble \& Alves (2017a) considered this taxon synonym of $C$. lapidosa Ravenna, a species described for Corrientes,
Argentina (Ravenna 1981b), from which C. altouruguaya presents many differences. In the original description and also in the label of the isotype of C. lapidosa, flowers are characterized as orange ( $v s$. yellow) and measurements of plant traits are significantly distinct from those of $C$. altouruguaya. Cypella lapidosa has lower valves of spathes of 1.3-1.7 cm long (vs. 2.4-3.9 cm), upper valves of 2.3-3.2 $\mathrm{cm}$ long $(v s .4-6.3 \mathrm{~cm}$ ) and adaxial crests of $1.3-1.5 \mathrm{~mm}$ long (vs. 4-6 mm). Also, androecium of C. lapidosa shows filaments ca. $2.8 \mathrm{~mm}$ long with $2 \mathrm{~mm}$ connate and incrassate at the base, while $C$. altouruguaya has filaments entirely free, 3-3.5 mm long. Due to all this contrasting differences, we consider $C$. altouruguaya as a distinct species.

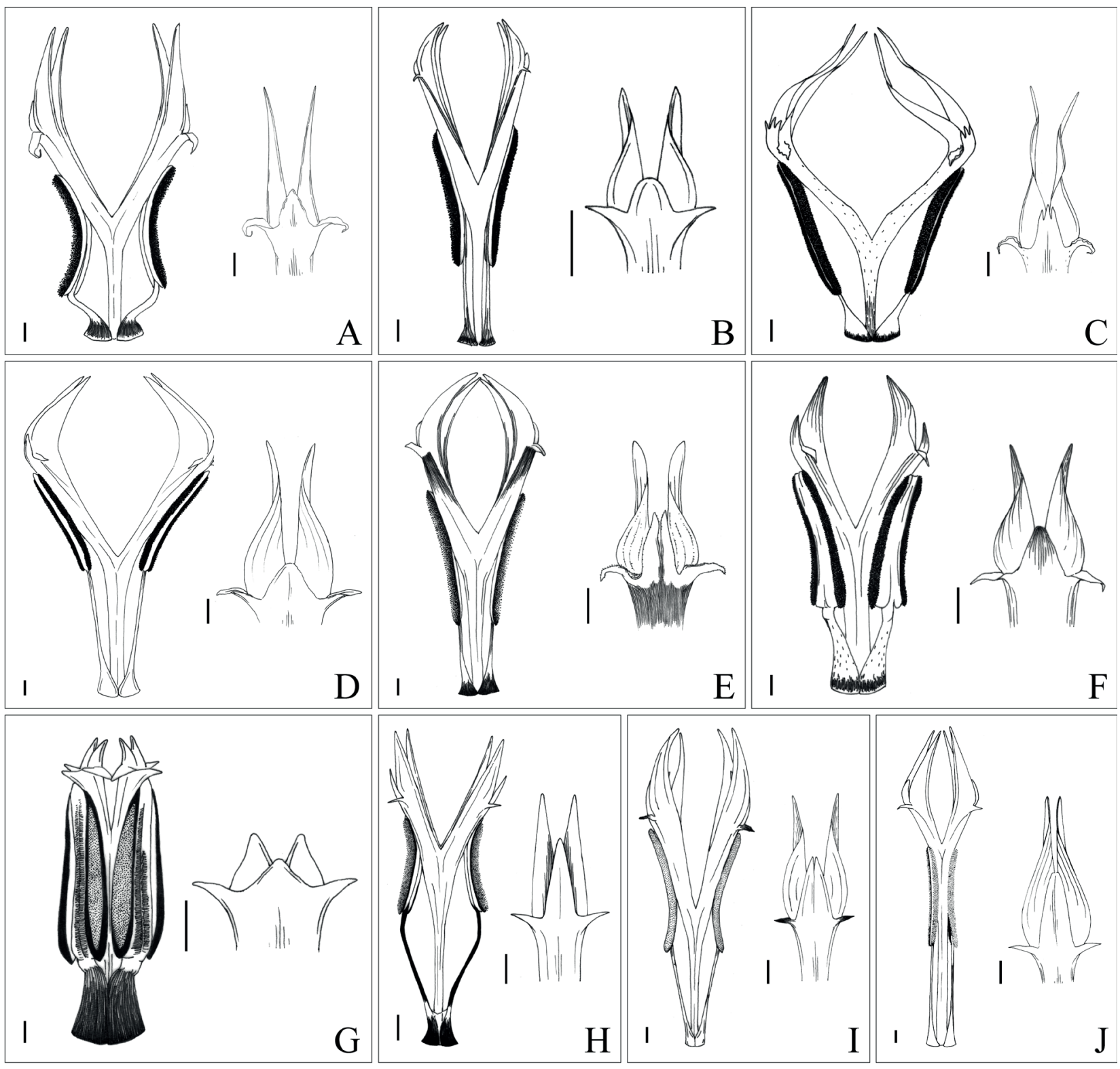

Figure 2. Androgynoecium (except ovary) and detail of style crests of yellow flowered species of Cypella. A. C. altouruguaya. B. C. aquatilis. C. C. armosa. D. C. charruana. E. C. crenata. F. C. guttata. G. C. herbertii subsp. brevicristata. H. C. pusilla. I. C. ravenniana. J. C. rivularis. Scale bars: $1 \mathrm{~mm}$. Drawings by R. Marchioretto. 
Specimens examined: Brazil. Rio Grande do Sul: Trindade do Sul, 18 August 2012, L. Eggers \& O. Chauveau 716 (ICN); idem, 5 December 2013, L. Eggers \& O. Chauveau 884 (ICN, MBM).

Cypella amplimaculata Chauveau \& L.Eggers, Phytotaxa 174(1): 29. 2014. Type: Brazil. Rio Grande do Sul: Piratini, 25 October 2011, A.M. Aita 49 (Holotype ICN!).

Figs. 3A, 4B.

Herb 27-64 cm high; basal leaves linear, 0.45-0.7 cm wide. Synflorescence of 2-5 pedunculate one-flowered rhipidia. Spathes lower valve $2-4 \mathrm{~cm}$ long, upper $4.1-$ $5.6 \mathrm{~cm}$ long. Flowers orange, 45-60 mm diameter. Outer tepals pandurate, proximally concave, distally reclinate, with dark red to purple streaks proximally and a conspicuous purple to purplish-red longitudinal central stripe from the constricted region; inner tepals cuneate, assurgent proximally, then incurved and abruptly reclinate distally, proximally densely streaked with purple, distally orange with white central portion and dense oblong orange-yellow area of elaiophores, laterally streaked with purple and apically spotted purple. Filaments connate basally for $0.1-0.2 \mathrm{~mm}, 2.2-3.5 \mathrm{~mm}$ long; anthers 5.2-6.2 mm long; connective whitish to pale orange-yellow, $0.7-1 \mathrm{~mm}$ wide; pollen ochraceous. Style whitish to pale yellow, 5-6 mm long; style arms pale yellow to orange, $4.5-5 \mathrm{~mm}$ long, crests orange. Adaxial crests, 2, erect, falcate inwards, longitudinally twisted at the base, 4-5 mm long, abaxial crest triangular, slightly lobed. Capsule obovoid-truncate.

Iconography: Chauveau et al. (2014).

Distribution, habitat, and phenology: Cypella amplimaculata occurs in the state of Rio Grande do Sul, in the Pampa and the Atlantic Rainforest Biomes. It grows in grasslands and usually is represented by scattered individuals. Altitude records range from 87 to $661 \mathrm{~m}$ a.s.l. (Chauveau et al. 2014). Flowering and fruiting individuals were collected from September to January, March, April and June.

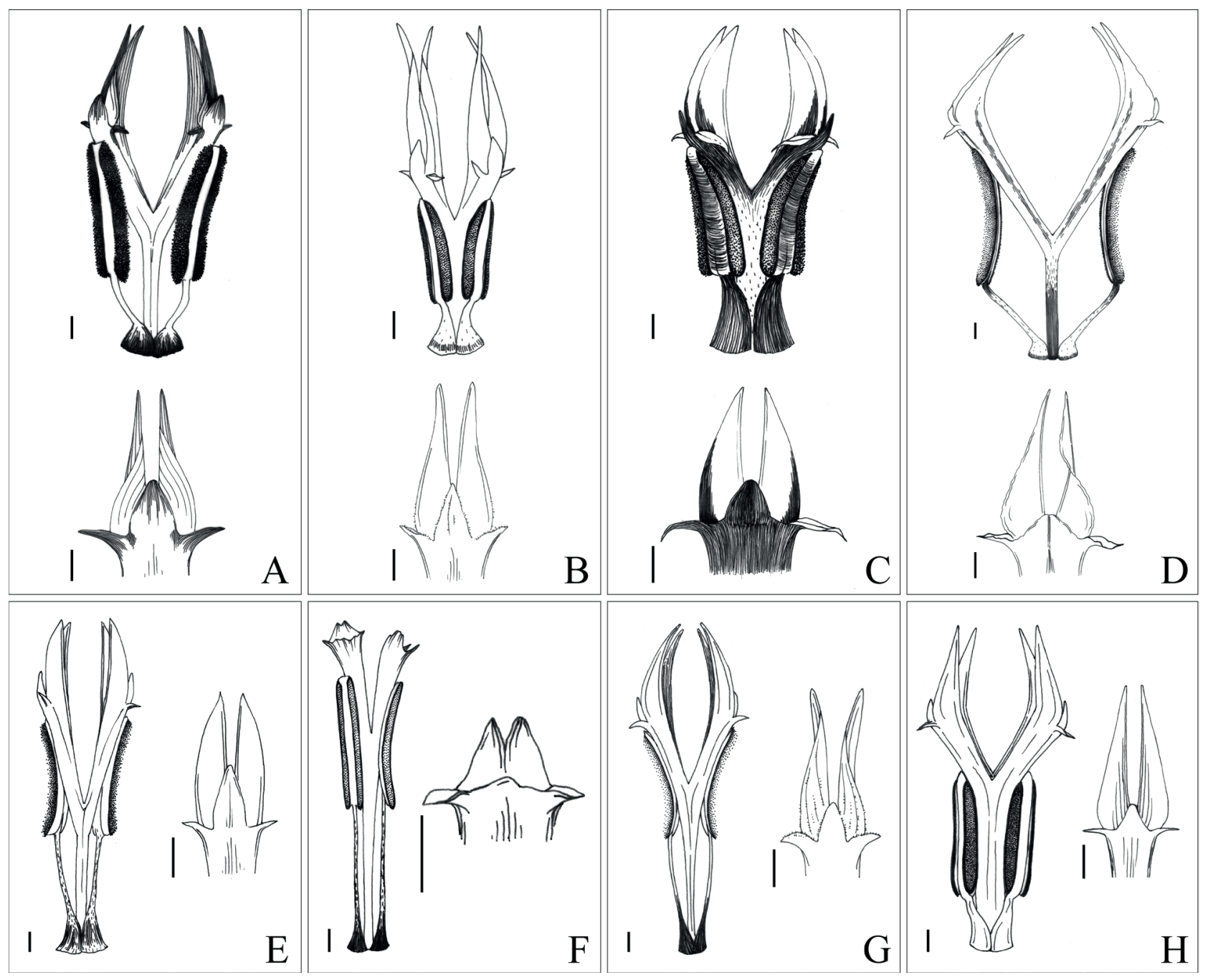

Figure 3. Androgynoecium (except ovary) and detail of style crests of orange (A, B, C, D) and white (E, F, G, H) flowered species of Cypella. A. C. amplimaculata. B. C. fucata. C. C. herbertii subsp. herbertii. D. C. magnicristata. E. C. discolor. F. C. hauthalii subsp. minuticristata. G. C. hauthalii subsp. opalina. H. C. luteogibbosa. Scale bars: $1 \mathrm{~mm}$. Drawings by R. Marchioretto. 
Conservation status: According to the IUCN Red List guidelines (IUCN 2017), the species is still considered as Nearly Threatened - NT (Chauveau et al. 2014).

Notes: Cypella amplimaculata was recently considered synonym of C. exilis Ravenna by Deble \& Alves (2017a). Cypella exilis was published as a new name for Polia gracilis Klatt (Klatt 1861-62) in 1981 (Ravenna 1981a). Polia gracilis was described by Klatt based on five specimens from "Brasilia meridionalis, Montevideo", collected by Sellow in a trip from Aceguá to Pelotas and surronding places, in the state of Rio Grande do Sul, in the year of 1824. Flowers were characterized as "violaceous", probably due to the analysis of dried samples, since the unique remaining voucher of the species (F. Sellow d.2077) does not provide any indication of flower colour. The other vouchers used by Klatt to describe P. gracilis were burned during the Second World War.

In 1877, a new combination of Polia gracilis was made by Baker (1877) as C. gracilis (Klatt) Baker, and it was illegitimate since the name $C$. gracilis (Herb.) Klatt (Klatt 1861-62) was already used to describe the species currently named Neomarica gracilis (Herb.) Sprague. Baker (1892) stated that the flower could be "bright yellow or tinged lilac" and different vouchers examined by us (such as the ones used by Baker) indicate that the flower colour is yellow. In the description of 1892, Baker cited three vouchers different from the ones used by Klatt and, among these, two different species can be retrieved: $C$. crenata (Vell.) Ravenna and C. pusilla (Link \& Otto) Benth. \& Hook.f. ex B.D.Jacks. Also, other specimens collected by Hassler and identified by Baker as C. gracilis (Chodat \& Hassler 1903) are actually $C$. armosa Ravenna. Due to the few original material of Polia gracilis and the problems related to the binomial $C$. gracilis, deep uncertainties remain concerning the true nature of $C$. exilis, and the only reliable information available for this species is the original description made by Klatt, and complemented in 1871 (Klatt 1871), as well
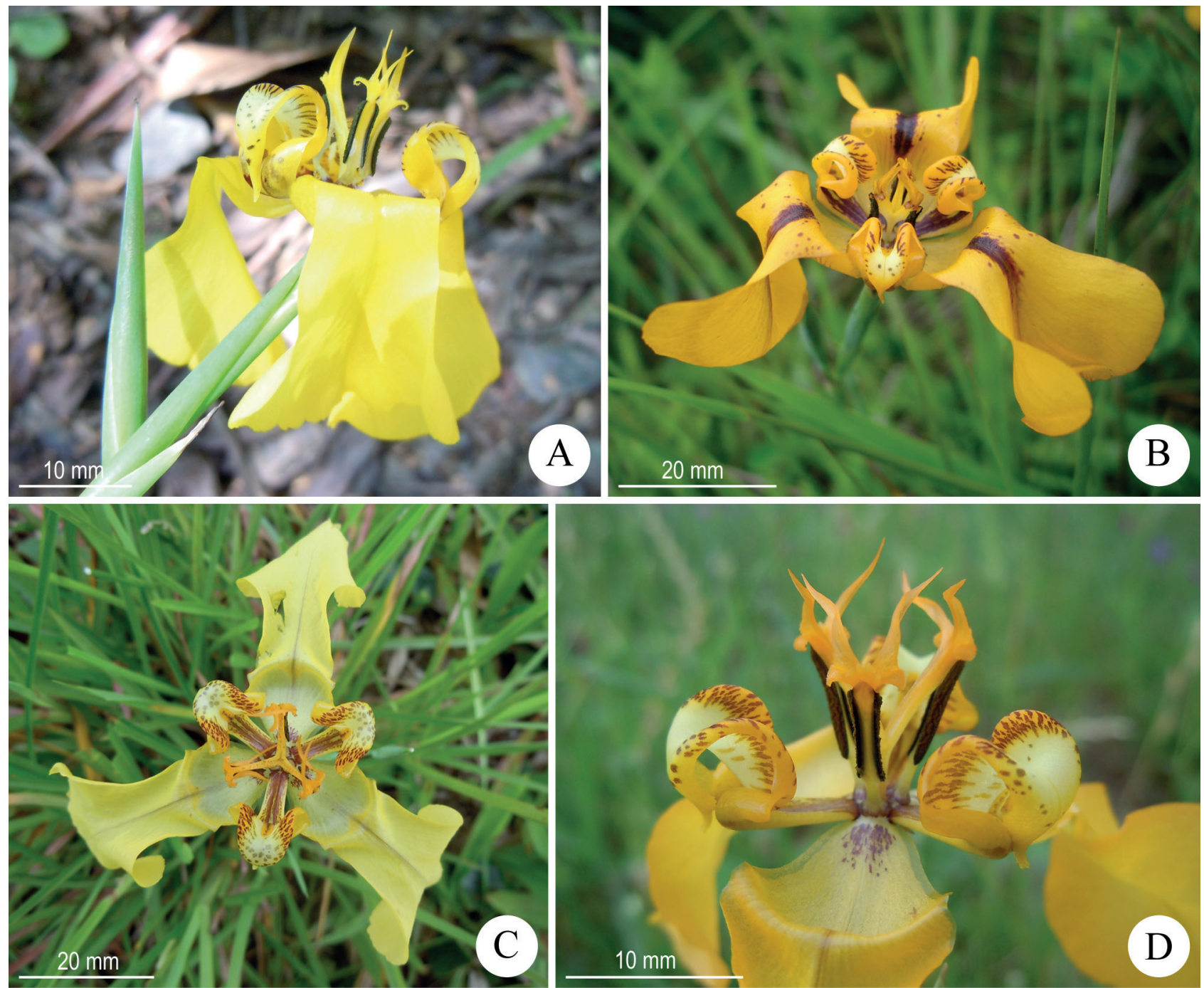

Figure 4. Flowers of Cypella spp. A. Cypella altouruguaya, lateral view. B. C. amplimaculata, apical inclinate view. C-D. C. armosa. C. apical view D. detail of androgynoecium. From: A. L. Eggers \& O. Chauveau 716 (ICN); B. A.M. Aita 49 (ICN) (photo A.M. Aita); C-D. L. Eggers et al. 761 (ICN). 
as the lectotype of the species (F. Sellow d.2077) (Klatt 1861-62; Deble \& Alves 2017a).

Associating data from the original description and information on area of occurrence of species, Deble \& Alves (2017a) pointed out three possible identities for $C$. exilis: C. fucata Ravenna, C. herbertii (Lindl.) Herb. and $C$. amplimaculata, and reported that only $C$. amplimaculata had habit and flower features that ressemble F. Sellow d.2077. However, comparing the original description of C. amplimaculata (Chauveau et al. 2014) and the available measurements of Polia gracilis from Klatt (1861-62; 1871), the following character states are quite different: basal leaves length and width [(8.5-)25-56.5(-65.5) $\times(0.15-)$ $0.45-0.7(-0.9) \mathrm{cm} v s .7 .62-12.70 \times 0.11 \mathrm{~cm}$ for C. exilis], spathes lower valve length [2-4 cm vs. $1.27-1.69 \mathrm{~cm}$ ], spathes upper valve length [(3.6-)4.1-5.6(-6.4) cm vs. 3.8 $\mathrm{cm}]$, ovary length [(7-)8-9.5(-11) $\mathrm{mm} v \mathrm{~s} .3 .17 \mathrm{~mm}]$, outer tepals length and width [(27-)32-36(-39) $\times(19-) 22-28 \mathrm{~mm}$ vs. $19.04 \times 6.35 \mathrm{~mm}$ ], inner tepals length and width [10$11(-12) \times 7-9 \mathrm{~mm} v s .4 .23-6.35 \times 4.23 \mathrm{~mm}$ ], capsule length [11-20 $\mathrm{mm}$ vs. $6.3 \mathrm{~mm}$ ]. Cypella amplimaculata is a stouter plant compared with $C$. exilis, as also can be observed in Fig. 6 of Deble \& Alves (2017a). Thus, objective reasoning acquired by the measurements does not provide unequivocal proof that $C$. exilis is $C$. amplimaculata and due to this degree of incertitude, $C$. exilis is still considered as a dubious taxon for the Brazilian flora.

Identity of the specimens cited as C. exilis by Deble \& Alves (2017a) could not be determined since the collections of this author were not found until now at Herbaria PACA and SI, as confirmed by the curators of both institutions.

Cypella amplimaculata is mostly similar to $C$. fucata, from which it can be distinguished by the brown central stripe of the outer tepals and the falcate adaxial crests of the style ( $v s$. erect in $C$. fucata). From $C$. herbertii subsp. herbertii, it can be differentiated by the colour of the connective (whitish to pale orange-yellow vs. dark red-brown to dark purple in C. herbertii subsp. herbertii), colour of the style arms (pale yellow to orange $v s$. proximally whitish with purple spots, distally red brown to dark purple) and crests (orange vs. proximally stained red-brown to purple).

Specimens examined: Brazil. Rio Grande do Sul: Amaral Ferrador, 11 October 2014, T. Pastori \& C. Forgiarini 111 (ICN); Arroio dos Ratos, 25 October 2013, C.D. Inácio et al. 139 (ICN); Bagé, 28 November 2014, T. Pastori \& O. Chauveau 185 (ICN); Caçapava do Sul, 12 November 2014, T. Pastori et al. 173 (ICN); Cachoeira do Sul, 18 April 2014, L. Eggers \& O. Chauveau 912 (ICN); Cambará do Sul, 16 January 2016, L. Eggers \& O. Chauveau 972 (ICN); Capão do Leão, 18 November 2006, L. Eggers \& T.T. Souza-Chies 192 (ICN); Cerrito, 18 November 2006, L. Eggers \& T.T. Souza-Chies 191 (ICN); Encruzilhada do Sul, 12 October 2014, T. Pastori \& C. Forgiarini 116 (ICN); Fontoura Xavier, 4 December 2013, L. Eggers \& O. Chauveau 883 (P); Guaíba, 9 November 2011, T.L.S. Alves 133 (ICN); Júlio de Castilhos, 17 October 2013,
L. Eggers et al. 823 (ICN); Lavras do Sul, 6 November 2014, T. Pastori et al. 154 (ICN); Porto Alegre, Morro da Polícia, 14 April 1986, E.R. Chini 12 (HAS); idem, Morro do Osso, 5 November 2016, M. Báez 217 (ICN); idem, Morro Santana, 23 September 2011, L. Eggers \& O. Chauveau 664 (MBM); idem, idem, 1 June 2012, T.L.S. Alves 220 (ICN); idem, idem, 19 March 2013, L. Eggers et al. 819 (ICN); idem, Morro São Pedro,15 December 2011, T.L.S. Alves 174 (ICN); idem, Morro Teresópolis, 5 October 2011, T.L.S. Alves 81 (ICN); Santa Maria, 3 October 1971, J.C. Lindeman et al. s.n. (ICN 8261); idem, 26 April 2017, L. Essi et al. 1096 (SMDB); Santana da Boa Vista, 12 November 2014, T. Pastori et al. 172 (ICN); Santana do Livramento, 17 October 2009, L. Eggers \& T.T. Souza-Chies 508 (ICN); Viamão, Parque Estadual de Itapuã, 30 November 2003, M. Pinheiro 435 (ICN).

Cypella aquatilis Ravenna, Nordic J. Bot. 1: 489. 1981. Type: Brazil. Rio Grande do Sul: Vacaria, "culta in Bonaria ex bulbis in rivulo ad Faz. da Ronda pr. Vacaria civit Rio Grande do Sul Braziliae collectis", January 1970, P. Ravenna 1037 (Holotype Herb. Ravenna, not seen; Isotype RB, not found). Lectotype: Brazil. Rio Grande do Sul: Vacaria, Faz. da Ronda, per. Vacaria, 3 January 1947, B. Rambo 34747 (PACA!) (Lectotype, here designated).

Figs. 2B, 5.

Herb 30-50 cm high; basal leaves linear to narrowly elliptic, 1.1-3.2 cm wide. Synflorescence simple or composed of 2-5 pedunculate two-flowered rhipidia. Spathes lower valve $1.8-2.7 \mathrm{~cm}$ long, upper $2.5-3.1 \mathrm{~cm}$ long. Flowers bright yellow, 35-50 mm diameter. Outer tepals pandurate, proximally concave, distally slightly reclinate to reflexed, with diminutive dark red spots and streaks proximally; inner tepals clawed, erecto-patent proximally, then slightly incurved and abruptly reclinate distally, proximally densely streaked with dark red, distally yellow with whitish central portion and dense oblong white area of elaiophores, laterally streaked with dark red and apically yellow. Filaments free, 3-6.5 mm long; anthers 5.3-7.5 mm long; connective pale yellow to ochre, $0.6-1 \mathrm{~mm}$ wide; pollen ochraceous. Style whitish to pale yellow, $5-8 \mathrm{~mm}$ long; style arms pale yellow, 5.2-7.2 mm long, crests pale light yellow. Adaxial crests, 2 , erect, falcate inwards, 2-4 mm long, abaxial crest rounded. Capsule obovoid-truncate.

Iconography: Pastori et al. (2018); Ravenna (1981a).

Distribution, habitat, and phenology: Cypella aquatilis occurs in the states of Paraná, Rio Grande do Sul and Santa Catarina, in the Atlantic Rainforest Biome (Ravenna 1981a). It is found in aquatic vegetation, associated with lotic environments, in river banks and in islets in the middle of rivers. Altitude records range from 200 to about 1000 $\mathrm{m}$ a.s.l. Flowering and fruiting individuals were collected from November to January, April and August.

Conservation status: Although Cypella aquatilis has been already considered Critically Endangered (CR) with criteria $\mathrm{D}$ in the evaluation of threatened flora species of 
Rio Grande do Sul state (Rio Grande do Sul 2014), upto-date collection database allowed analysis of Extent of Occurrence $\left(\mathrm{EOO}=61,266 \mathrm{Km}^{2}\right)$ and Area of Occupancy $\left(\mathrm{AOO}=44 \mathrm{Km}^{2}\right)$ to access geographical range $(\mathrm{B})$ criterion. Thus, threatened category was reviewed and, according to the IUCN Red List guidelines (IUCN 2017), it is now considered Endangered - EN, B2,a,b(iii,iv). The species is threated by the increasing implementation of hydroelectric projects, which is causing a decline of extent of occurrence and number of locations.

Notes: Since plants of Herbarium Ravenna are not available and the isotype from Herbarium RB was not localized, a lectotype was choosen among the provided paratypes of Ravenna (1981a).

Running water habitat and wide leaves are characteristic for species recognition since other hydrophytic taxa of Cypella are related to flooded areas or to small streams, and few species present leaf width over $1 \mathrm{~cm}$.

Specimens examined: Brazil. Paraná: Laranjeiras do Sul, 18 April 1970, G. Hatschbach 24169 (MBM); Rio Grande do Sul: Cambará do Sul, 8 December 1960, A. Schultz 2522 (ICN); idem, 11 January 1983, C.W. Ribeiro s.n. (HAS 17795); idem, 21 December 1995, C. Schlindwein
776 (MPUC); Caxias do Sul, 2 January 1946, B. Rambo s.n. (PACA 30918); Muitos Capões, 17 August 2012, L. Eggers \& O. Chauveau 714 (ICN); Pinhal da Serra, 22 January 2008, C.R. Grippa \& T.B. Guimarães 262 (ICN); São Francisco de Paula, 26 November 1998, B.E. Irgang s.n. (ICN); São José dos Ausentes, 18 December 1980, J. Goergem s.n. (ICN 49966); Santa Catarina: Campos Novos, 14 January 1999, B.E. Irgang s.n. (ICN 190667); Itapiranga, 11 November 1964, L.B. Smith \& R.M. Klein 13156 (NY, R).

Cypella armosa Ravenna, Wrightia 7(1): 20.1981. Type: Paraguay. Paraguari: San Bernardino, "in herbosis inundatis pr. San Bernardino Paraguariae”, February 1966, P. Ravenna 462 (Holotype Herb. Ravenna, not seen; Lectotype K!, here designated).

$=$ Cypella gracilis (Klatt) Baker f. humilis Baker, Bulletin de l'Herbier Boissier 2 (3): 1102. 1903. Lectotype: Paraguay, Paraguaria centralis, s.d., E. Hassler 1703 (Lectotype P!) (designated by Deble 2017); Isolectotypes BM [image!], G00038374 [image!]; G00076390 [image!]).

Figs. 2C, 4C-D.

Herb $20-58 \mathrm{~cm}$ high; basal leaves linear, $0.2-0.4 \mathrm{~cm}$ wide. Synflorescence simple or composed of $2-3$ pedunculate
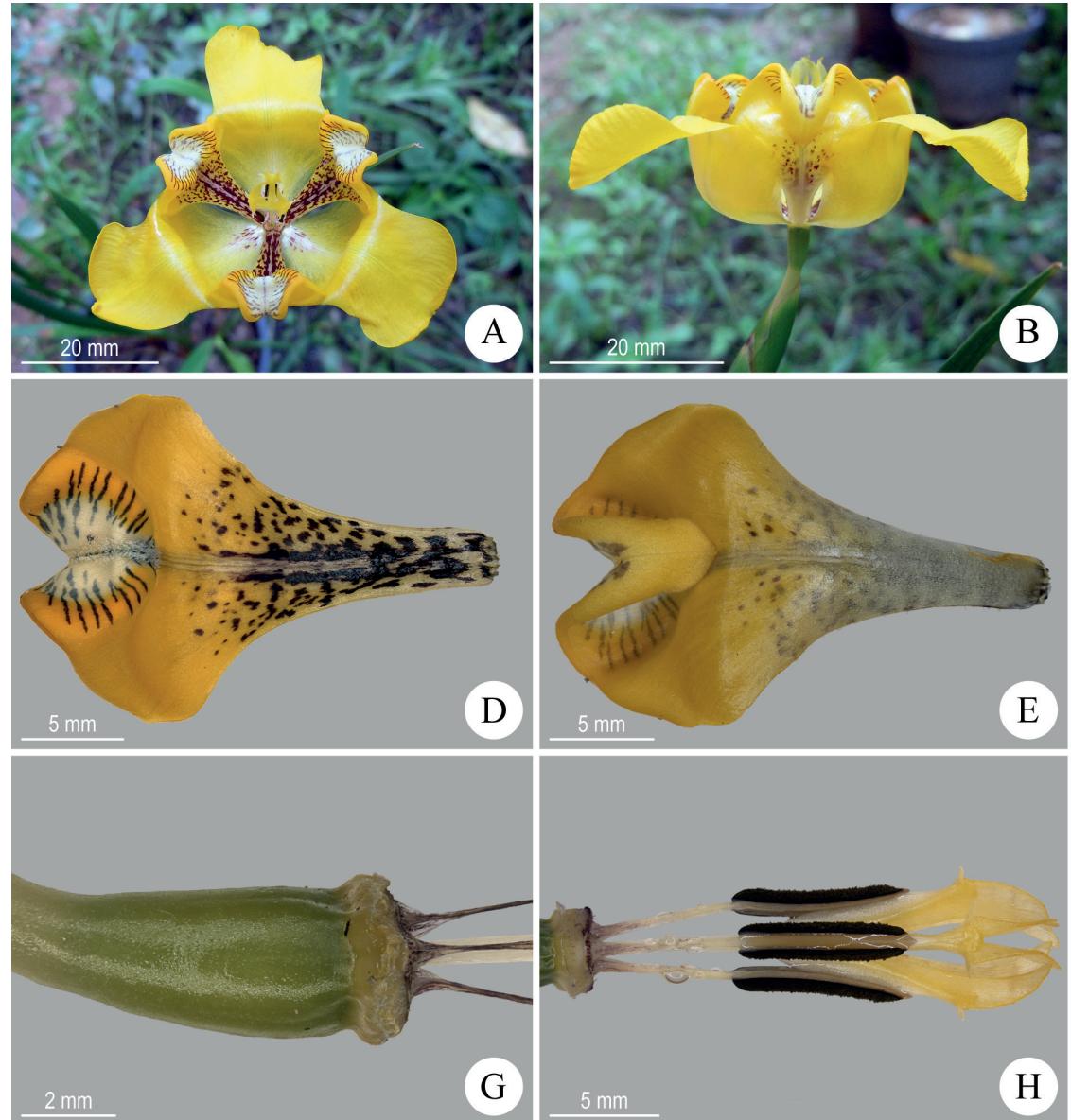
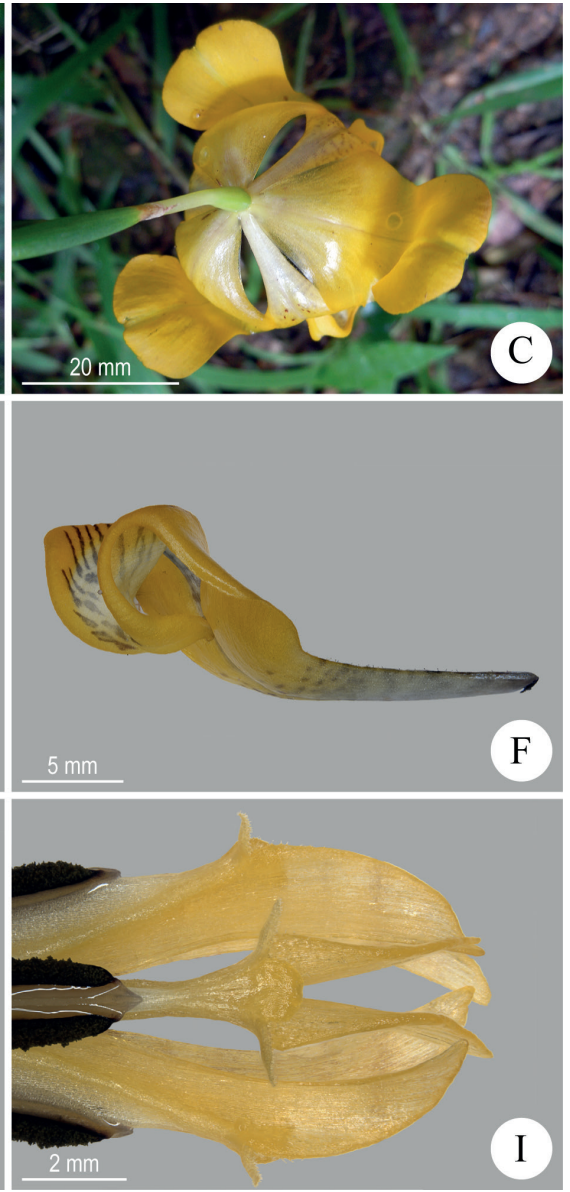

Figure 5. Cypella aquatilis. A-C. Flower. A. apical view B. lateral view C. basal view D-F. Inner tepal D. adaxial view E. abaxial view F. lateral view G. Ovary H. Stamens and style in lateral view I. Style crests and stigmatic replicatures. From: L. Eggers \& O. Chauveau 714 (ICN). 
one-flowered rhipidia. Spathes lower valve $2.3-2.8 \mathrm{~cm}$ long, upper $4.2-5.6 \mathrm{~cm}$ long. Flowers bright yellow, $50-65 \mathrm{~mm}$ diameter. Outer tepals spathulate-pandurate, proximally concave, distally patent to reclinate, with dark red streaks proximally; inner tepals clawed, erecto-patent proximally, then geniculate and reclinate distally, proximally densely streaked with dark red, distally yellow with light yellow central portion and dense oblong orange-yellow area of elaiophores, laterally spotted with dark red and apically yellow. Filaments free, 2.5-3.2 mm long; anthers 6-7 mm long; connective pale yellow, $0.7-1 \mathrm{~mm}$ wide; pollen ochraceous. Style yellow, $4.2 \mathrm{~mm}$ long; style arms orangeyellow, $6.5 \mathrm{~mm}$ long, orange-yellow. Adaxial crests, 2, divergent, falcate inwards, longitudinally twisted at the middle part, 5.5-7.5 mm long, abaxial crest lobed. Capsule obovoid-clavate.

Iconography: Deble et al. (2012b); Ravenna (1981b).

Distribution, habitat, and phenology: Cypella armosa occurs in the north-western region of the state of Rio Grande do Sul, in the Pampa Biome. The species is also distributed in the northeast of Argentina and south-central Paraguay (Ravenna 1981b; 2003; Roitman et al. 2008). It grows in grasslands, humid to inundated, with altitude records ranging from 50 to $500 \mathrm{~m}$ a.s.l. (Ravenna 2003). Flowering and fruiting individuals were collected from October to February and May.

Conservation status: Although C. armosa presents just a marginal geographic distribution in Southern Brazil, it is broadly distributed in Argentina and Paraguay. According to the IUCN Red List guidelines (IUCN 2017), it is still considered as Nearly Threatened - NT (Deble et al. 2012b).

Notes: Collection P. Ravenna 462 from Herbarium $\mathrm{K}$ was designated as the lectotype of $C$. armosa due to the unaccessibility of plants from Herbarium Ravenna. Also, barcode number of the lectotype of $C$. gracilis $\mathrm{f}$. humilis designated by Deble (2017) is here corrected to P02061541, since barcode P02065401 corresponds to a collection of Gladiolus unguiculatus Baker, from French Guiana.

Cypella armosa presents distinctive style arms and crests. Style arms are typically divergent and adaxial crests are long $(5.5-7.5 \mathrm{~mm})$ and longitudinally twisted in the middle portion (Fig. 2C). The most similar species is $C$. altouruguaya, as previously discussed.

Specimens examined: Brazil: Rio Grande do Sul: São Borja, 8 November 2012, L. Eggers et al. 761 (ICN).

Additional examined specimens: Argentina: Chaco, Primero de Mayo, 11 December 1931, A.G. Schulz 209 (SI); idem, November 1941, A.G. Schulz 1808 (SI); idem, November 1949, A.G. Schulz 7430 (IAC); Corrientes, Concepcion, 2 February 1963, E. Cano \& J. Cámara Hernández 646 (BAA); idem, 22 December 1988, T.M. Pedersen 15126 (CTES, MBM); idem, San Martín, 5 October 2013, W.A. Medina et al. 407 (ICN); idem, Santo Tomé, 18 November 1994, M.M. Arbo et al. 6455 (CTES); idem, 11 February
2001, G. Roitman \& A. Castillo s.n. (BAA 24955); idem, cf. Ituzaingó, Paraje Galarza, 23 November 1999, M.M. Arbo et al. 8420 (CTES); idem, Ituzaingó, 14 May 2004, G.E. Barboza et al. 1013 (CORD); idem, San Miguel, 27 October 1960, L.A. Espinar 1084 (CORD); idem, 24 November 1993, M.M. Arbo et al. 6036 (CTES); idem, San Roque, 25 February 2006, S.S. Denham \& N.B. Deginani 130 (CTES, SI); idem, Capital, 12 October 1967, A. Krapovickas \& C.L. Cristobal 13590 (CTES); idem, December 1975, R. Martinez Crovetto 10111 (CTES); Formosa, 15 November 1900, illegible 6141 (SI 37874); idem, 7 November 1903, illegible s.n. (SI 37871); idem, February 1918, P. Jorgensen 2294 (BA, MVM, SI); idem, Pilcomayo, 7 January 1980, E.R. Guaglianone et al. 450 (SI); Misiones, Apóstoles, 11 October 1977, A.L. Cabrera et al. 28556 (SI); Santa Fé, General Obligado, 10 December 1945, R. Maldonado 1680 (LP). Paraguay: "Paraguaria Septentrionales”, 5 January 1908, K. Fiebrig 5362 (G); Alto Paraguai, 2 November 1954, A. Woolston 360 (SI); Cordillera, Cordillera de Altos, s.d., E. Hassler 4078 (G, P); Misiones, 5 Mayo 1945, Rojas 12682 (K); Ñeembucu, 27 October 1991, R. Spichiger et al. 5283 (G); Paraguarí, January 1878, B. Balansa 536 (G, K); Presidente Hayes, 11 November 1985, D.R. Brunner 1353 (G).

Cypella charruana Deble \& F.S. Alves, Darwiniana 3(2): 237. 2015. Type: Brazil. Rio Grande do Sul: Santana do Livramento, 15 November 2014, L.P. Deble et al. 15108 (Holotype SI [image!]; Isotypes MVFA, not seen; PACA, not found).

Figs. 2D, 6A.

Herb 20-40 cm high; basal leaves linear-ensiform, 0.2$0.5 \mathrm{~cm}$ wide. Synflorescence simple or composed of 2-3 pedunculate one-flowered rhipidia. Spathes lower valve 1.7$2.5 \mathrm{~cm}$ long, upper 3-3.5 cm long. Flowers golden-yellow, 40$55 \mathrm{~mm}$ diameter. Outer tepals distintly clawed, proximally concave, distally reflexed, stained purplish-brown proximally; inner tepals clawed, erecto-patent proximally, then assurgent and reclinate distally, mostly yellow, proximally streaked with purplish-brown, distally yellow with yellow-cream central portion and yellow area of elaiophores, laterally streaked with purplish-brown and apically golden-yellow. Filaments connate basally for $0.5-0.8 \mathrm{~mm}, 8.4-10.5 \mathrm{~mm}$ long; anthers 8-9.5 mm long; connective yellow, $0.4-0.5 \mathrm{~mm}$ wide; pollen yellow or ochraceous. Style yellow, 8-9 mm long; style arms yellow, 9-10 mm long, crests yellowish. Adaxial crests, 2, erect, falcate inwards, $4.5-6.5 \mathrm{~mm}$ long, abaxial crest deltate. Capsule obovoid-obloid.

Iconography: Deble et al. (2015a).

Distribution, habitat, and phenology: Cypella charruana occurs in the south-western region of the state of Rio Grande do Sul, in the Pampa Biome; and in northern Uruguay. It grows in grasslands, in moist soils. Altitude records range from 220 to $380 \mathrm{~m}$ a.s.l. (Deble et al. 2015a). Flowering and fruiting occurs from November to January (Deble et al. 2015a). 


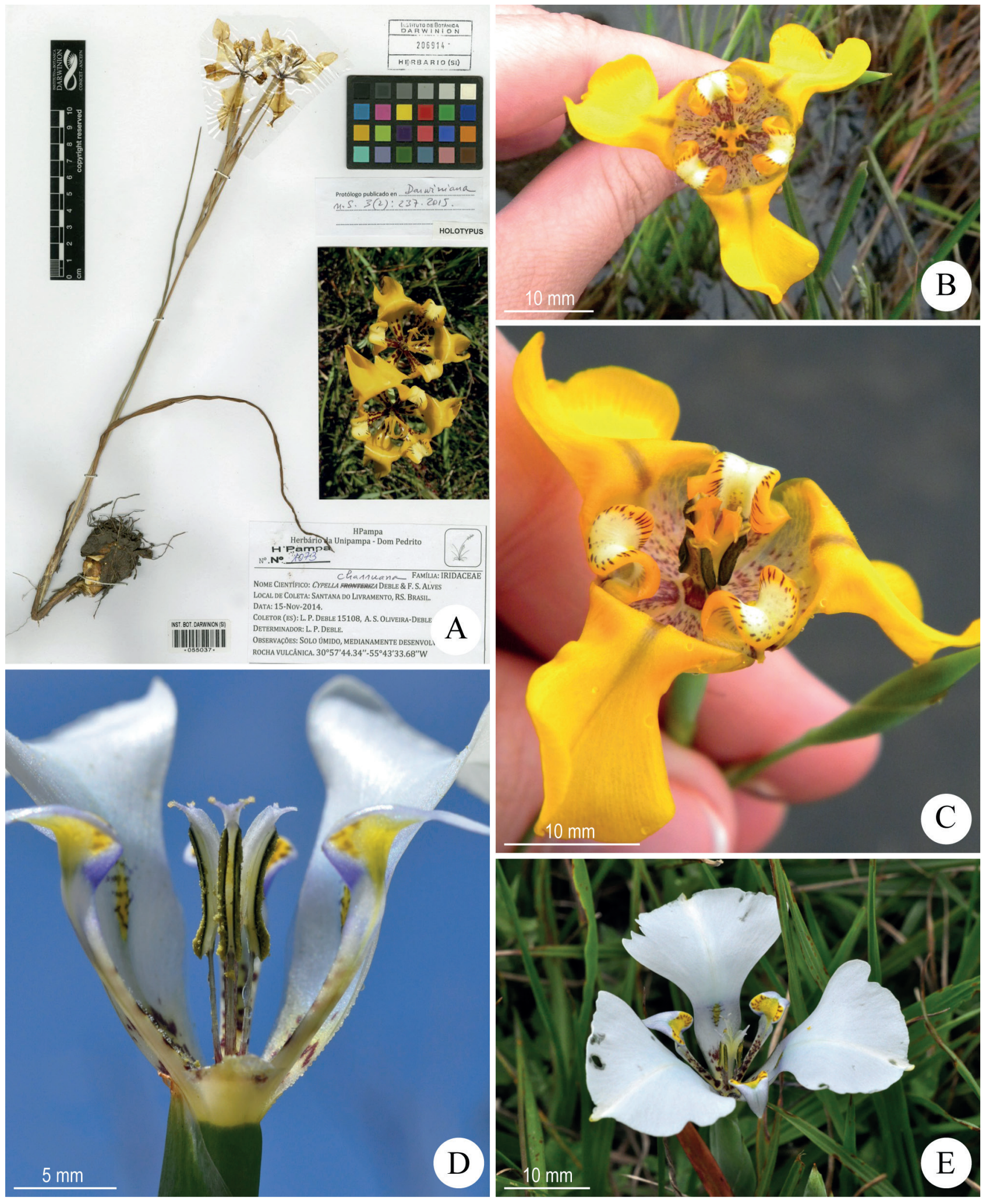

Figure 6. Exsiccate and flowers of Cypella spp. A. Cypella charruana Holotype, Deble et al. 15108 (SI) B-C. C. guttata. B. apical view C. apical inclinate view D-E. C. hauthalii subsp. minuticristata. D. lateral view, with one outer tepal removed E. apical inclinate view. From: B-C. T. Pastori \& R. Borges 204 (ICN) (photos T. Pastori); D. L. Eggers et al. 827 (ICN); E. L. Eggers et al. 833 (ICN). 
Conservation status: The species was categorized as Critically Endangered - CR, B1, B2a,b(iii), D by Deble et al. (2015a). There are no additional collections or other elements to justify new categorization, thus conservation status is accepted and maintained.

Notes: Among other features, C. charruana can be characterized by the distinctly clawed outer tepals that produce a perigon with conspicuous gaps between tepals. It can be differentiated from $C$. ravenniana by the longer filaments (8.4-10.5 $\mathrm{mm}$ vs. 5.9-6.5 $\mathrm{mm}$ ) and longer anthers (8-9.5 mm vs. 6.5-7.8 mm). From C. guttata, it can be distinguished by the filiform filaments (vs. linear to triangular), longer adaxial crests $(4.5-6.5 \mathrm{~mm}$ vs. $2.5-3.5 \mathrm{~mm}$ ) (Fig. 2D vs. 2F), and also by the clawed outer tepals.

Specimens examined: Brazil. Rio Grande do Sul: Santana do Livramento, 15 November 2014, L.P. Deble et al. 15109 (SI); idem, 15 November 2014, L.P. Deble et al. 15110 (SI); idem, 2 January 2015, L.P. Deble \& A.S. OliveiraDeble 15112 (SI).

Cypella crenata (Vell.) Ravenna, Bol. Soc. Argent. Bot. 10(4): 312-322. 1965.
ESisyrinchium crenatum Vell., Fl. Flumin. 9: tab. 67. 1831 (1827). Lectotype: Original plate of Flora fluminensis in the Manuscript Section of the Biblioteca Nacional, Rio de Janeiro [cat. no.: mss1198658_071] and later published in Vellozo, Fl. Flumin. Icones 9: tab. 67. 1831. (Lectotype, here designated). Epitype: Brazil. Minas Gerais: Caldas, 22 November 1874, A.F. Regnell - C.W.H. Mosén III 1216 (Epitype S-12-16048 [image!], here designated; Isoepitype S-12-16047 [image!]).

= Cypella paludosa Klatt, Abh. Naturf. Ges. Halle 15: 365. 1882. Type: Brazil. Minas Gerais: Caldas "Brasilia, Caldas, prov. Minarum in paludosis”, 8 November 1854, A.F. Regnell III 1216 (Holotype presumed lost). Neotype: Brazil. Minas Gerais: Caldas, 18 January 1870, A.F. Regnell III 1216 (Neotype US01268564 [image!], here designated).

= Cypella laxa Ravenna, Wrightia 7(1): 15. 1981. Type: Brazil. Paraná: Guarapuava, "in uliginosis circ. 2 km a Posto Agropecuario", 3 December 1969, P. Ravenna \& G. Hatschbach 1008 (Holotype Herb. Ravenna, not seen; Isotype RB, not found; Lectotype K!, here designated), syn. nov.

Figs. 2E, 7.

Herb 30-100 cm high; basal leaves linear, 0.1-0.3 $\mathrm{cm}$ wide. Synflorescence simple or composed of 2-3
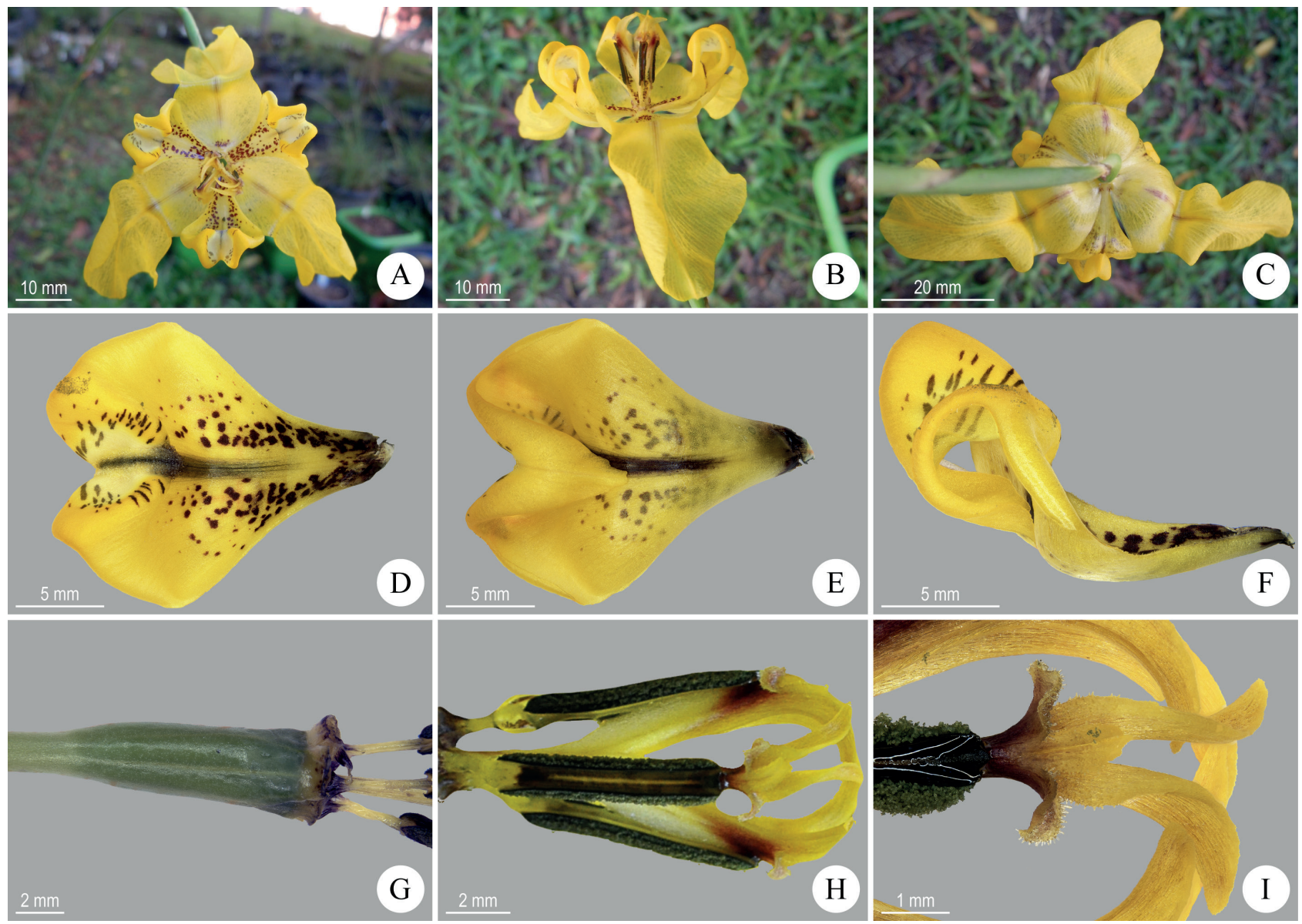

Figure 7. Cypella crenata. A-C. Flower. A. apical view B. lateral view C. basal view D-F. Inner tepal D. adaxial view E. abaxial view F. lateral view G. Ovary H. Stamens and style in lateral view I. Style crests and stigmatic replicatures. From: A-C. L. Eggers et al. 766 (ICN); D-I. L. Eggers et al. 830 (ICN). 
pedunculate one-flowered rhipidia. Spathes lower valve $1.7-4.1 \mathrm{~cm}$ long, upper $3.3-5.1 \mathrm{~cm}$ long. Flowers yellow, 30-50 mm diameter. Outer tepals pandurate, proximally concave, distally reclinate to reflexed, with brownish-red streaks proximally; inner tepals cuneate, erecto-patent proximally, then slightly incurved and abruptly reclinate distally, proximally with brownish-red spots, distally yellow with whitish to pale yellow central portion and yellowish dense area of elaiophores, laterally sparsely streaked with light brown and apically yellow. Filaments free, 3-4 mm long; anthers 7-8.2 mm long; connective pale yellow to red-brown, less than $0.5 \mathrm{~mm}$ wide; pollen ochraceous. Style light yellow, 5.5-6.8 $\mathrm{mm}$ long; style arms proximally light yellow, distally red-brown, 6-6.7 mm long, crests yellow to light yellow. Adaxial crests, 2, strongly falcate inwards, 3.2-4 mm long, abaxial crest elliptic, entire to bipartite. Capsule ellipsoid-clavate.

Iconography: Vellozo (1831 [1827]), as Sisyrinchium crenatum.

Distribution, habitat, and phenology: Cypella crenata occurs in the states of Mato Grosso do Sul, Minas Gerais, Paraná, Rio Grande do Sul, Santa Catarina and São Paulo, encompassing the Atlantic Rainforest, the Cerrado and the Pampa Biomes. It is also distributed in northeastern Argentina (Roitman \& Castillo 2003) and Paraguay (Ravenna 2000; 2003; Roitman et al. 2008). It is found in aquatic vegetation, such as bogs, and in humid grasslands (Ravenna 1965; 1981b; 2000; 2003), with altitude records ranging from 140 to $1300 \mathrm{~m}$ a.s.l. Flowering and fruiting occurs from September to March, and May.

Conservation status: According to the IUCN Red List guidelines (IUCN 2017), the species is considered as Nearly Threatened (NT), but may qualify for higher threatened category in the future, particularly because of decline quality and loss of habitat through substitution or drainage of natural flooded areas. Cypella crenata was considered Critically Endangered (CR) in the evaluation of threatened flora species of Rio Grande do Sul state (Rio Grande do Sul 2014, as C. laxa), but expanded knowledge of geographical distribution of the species in the Brazilian country qualifies the new categorization.

Notes: The new combination to the binomial Cypella crenata was created by Ravenna (1965) based on Sisyrinchium crenatum Vell. published in Florae Fluminensis (Vellozo 1831 [1827]). No collection was ever found for the state of Rio de Janeiro, but the species was reported to occur in São Paulo and Minas Gerais (Ravenna 1965). Subsequently, Ravenna (1981b) described the yellow-flowered C. laxa from Paraná and Santa Catarina, and differentiated it from C. crenata by flower colour, texture of outer tepals and length of filaments. Cypella crenata was characterized as presenting texture of the outer tepals firmer, and filaments erect, longer than those of C. laxa. Although the yellow-flowered C. paludosa Klatt was cited as synonym of $C$. crenata (Ravenna 1965), flowers of this species were reported to be orange (Ravenna 1981b).
Exsiccates and original descriptions of $C$. crenata, $C$. laxa and C. paludosa were examined, and no morphological differences were found to segregate the taxa. The continuity of the areas of distribution of the species consolidates our reasoning that the names belong to a unique species in its morphological range of variation and geographical distribution. Hence, C. laxa and C. paludosa are here considered synonyms of $C$. crenata. The illustration of Vellozo's Florae Fluminensis was chosen as lectotype, and the collection S-12-16048 of A.F. Regnell - C.W.H. Mosén III 1216 for the Regnellian Herbarium cited in Ravenna (1965) was selected as epitype. Collection A.F. Regnell III 1216 (US01268564) was chosen as neotype of C. paludosa, because date of collection does not correspond to the material reported at the protologue. Lastly, the isotype of $P$. Ravenna \& G. Hatschbach 1008 at K was selected as lectotype of $C$. laxa, once the holotype at Herbarium Ravenna is not available and the isotype at RB was not found.

Cypella crenata is a tall plant, up to $1 \mathrm{~m}$ high, usually with a synflorescence of one or few rhipidia, which can be recognized by the habitat and the style arms and style crests features. It occurs generally in bogs or flooded areas and exhibits adaxial crests up to $3.5 \mathrm{~mm}$ long. Furthermore, the red-brown colour of the distal part of the style arms is particular of the species (Figs. 2E, 7H).

Specimens examined: Brazil. Mato Grosso do Sul: Terenos, 20 May 2010, V.J. Pott et al. 10902 (CGMS); Minas Gerais: Caldas, 20 November 1873, A.F. Regnell - C.W.H. Mosén 1048 (K, P); idem, s.d., Regnell III 1216 (P); Paraná: Contenda, 22 October 1967, G. Hatschbach 17551 (MBM); Curitiba, 30 October 1973, G. Hatschbach 32778 (MBM); idem, 30 November 1973, G. Hatschbach 33430 (MBM); Guarapuava, 6 December 1968, G. Hatschbach \& O. Guimarães 20517 (MBM, MO); Marmeleiro, 25 October 1969, G. Hatschbach 22668 (MBM, MO, UPCB); idem, 21 February 1971, G. Hatschbach 26409 (MBM); Palmas, 13 December 1966, G. Hatschbach 15419 (MBM, NY, US); idem, 6 December 1971, G. Hatschbach et al. 28291 (MBM); Piraí do Sul, 17 November 1970, G. Hatschbach \& O. Guimarães 25400 (CTES, MBM, MO, NY, UEC, UPCB, US); idem, 24 November 1980, G. Hatschbach 43365 (MBM); Piraquara, 22 November 1952, G. Hatschbach 3127 (MBM, SI, US); idem, 12 November 1973, G. Hatschbach 33411 (MBM); Rio Grande do Sul: Bom Jesus, 16 January 2011, J.R.V. Iganci et al. 807 (ICN); Ciríaco, 6 December 2013, L. Eggers \& O. Chauveau 890 (ICN); São Pedro do Sul, 31 October 2009, L. Eggers \& T.T. Souza-Chies 559 (ICN); idem, 4 November 2012, L. Eggers et al. 730 (ICN); Soledade, 2 November 2013, L. Eggers et al. 830 (ICN); Santa Catarina: s.l., January 1891, E. Ule 1915 (P); Água Doce, 4 December 1964, L.B. Smith \& R.M. Klein 13517 (HBR, NY, P, R); idem, 6 December 1971, L.B. Smith et al. 15690 (NY, P); Irani, 8 November 1964, L.B. Smith \& R.M. Klein 13034 (R, US); idem 15 December 1964, L.B. Smith 13974 (NY, R, US); Joaçaba, 24 December 1956, L.B. Smith \& R. Reitz 9163 (US); Lages, 13 December 2004, L. Eggers \& T.T. Souza-Chies 95 (ICN); 
São Joaquim, 5 January 1965, L.B. Smith \& R. Reitz 14264 (US); São Paulo: São Paulo, Vila Ema, December 1932, A.C. Brade 12255 (RB); idem, idem, December 1933, A.C. Brade 12849 (RB); idem, idem, October 1938, F. Markgraf 3067 (RB).

Additional examined specimens: Argentina: Corrientes, Lagarza, 25 November 1999, M.M. Arbo et al. 8512 (CTES); Misiones, Candelaria, 26 March 2002, G. Roitman \& G.H. Tourn s.n. (BAA 24928); idem, Loreto, 10 September 1949, J.E. Montes 5115 (BAB). Paraguay: N. Paraguai, November 1908-1909, K. Fiebrig 4212 (G, K); Alto Paraná, 11 November 1987, G. Caballero Marmori 1326 (CTES); Canindeyú, November s.a., E. Hassler 4886 (G); idem, 1898-1899, E. Hassler 5332 (G).

Cypella discolor Ravenna, Wrightia 7(1): 16. 1981. Type: Brazil. Rio Grande do Sul: "Culta in Bonaria ex bulbis ad Passo da Guarda civit”, December 1967, P. Ravenna 507 (Holotype Herb. Ravenna, not seen). Neotype: Brazil. Rio Grande do Sul: Quaraí, na localidade do Passo da Guarda, 16 December 2010, L.P. Deble \& A.S. Oliveira-Deble 12901 (designated by Deble \& Alves 2017a) (Neotype SI, not found; Isoneotypes CTES, not found; K, not seen; PACA, not found).

Figs. 3E, 8.
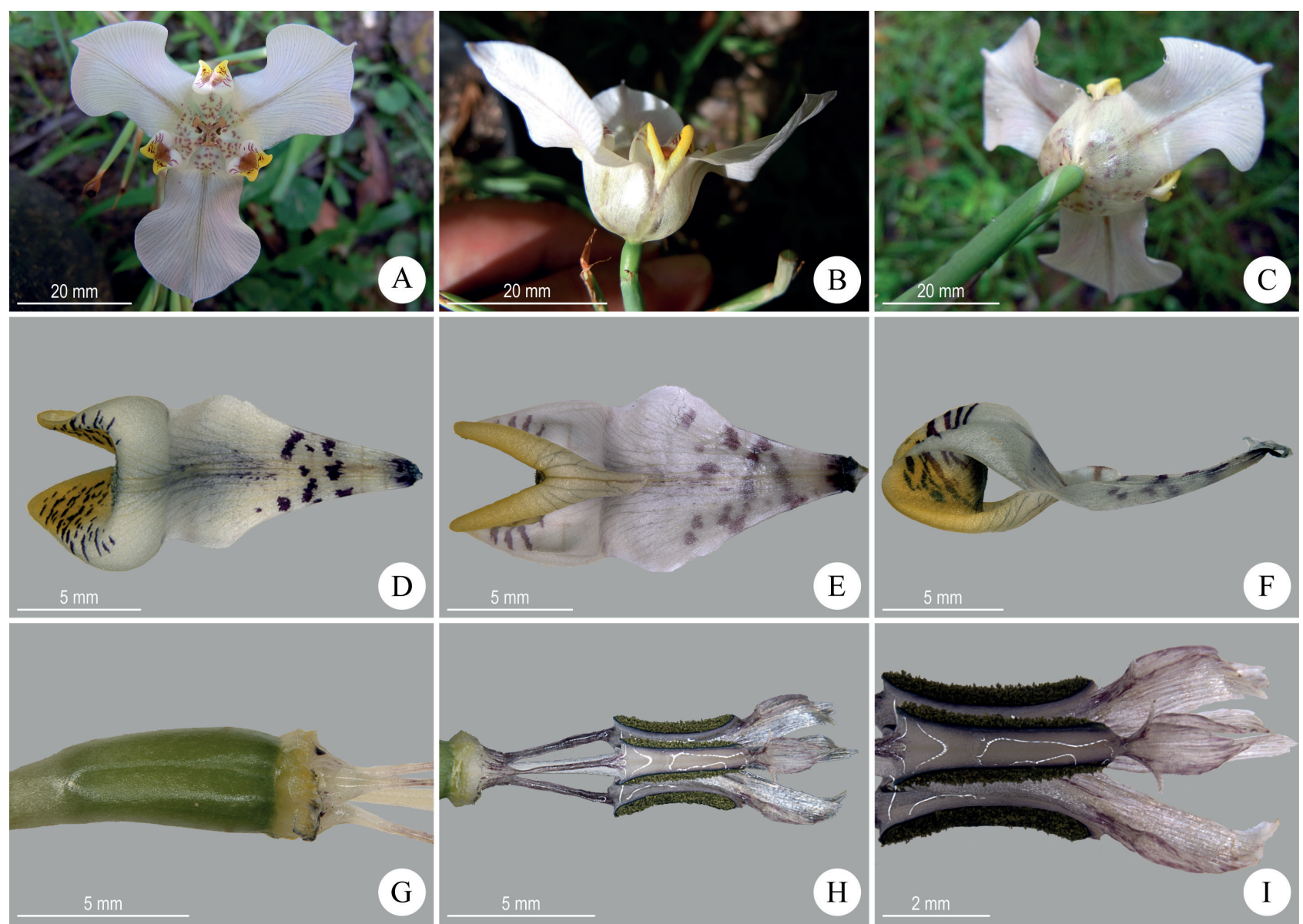

Figure 8. Cypella discolor. A-C. Flower. A. apical view B. lateral view C. basal view D-F. Inner tepal D. adaxial view E. abaxial view F. lateral view G. Ovary H. Stamens and style in lateral view I. Style crests and stigmatic replicatures. From: E.M. Stiehl-Alves 11 (ICN). 
Uruguay. It grows in stony grasslands, and was collected for the first time, near a stream, in low open woods (Ravenna 1981b). Altitude records are about $150 \mathrm{~m}$ a.s.l. Flowering and fruiting occurs from October to December and March (Deble et al. 2012a).

Conservation status: The species was re-evaluated for conservation status and categorization is maintained as Endangered - EN, B1, B2a,b(iii), D (Deble et al. 2012a).

Notes: Among the white flowered Cypella, C. discolor can be distinguished from both subspecies of $C$. hauthalii by the pandurate outer tepals, proximally concave (vs. clawed, proximally erect, attenuate outer tepals of $C$. hauthalii), forming a conspicuous perigon concave center. Outer tepals also differentiate $C$. discolor from $C$. luteogibbosa, since they are distally reflexed in the last species (vs. patent to reclinate in C. discolor).

Specimens examined: Brazil. Rio Grande do Sul: Quaraí, 5 November 2010, L. Dal Ri 2 (ICN); idem, 26 October 2011, A.M. Aita 75 (ICN); idem, 14 November 2013, E.M. Stiehl-Alves et al. 94 (ICN); Uruguaiana, 6 November 2012, L. Eggers et al. 745 (ICN).

Additional examined specimens: Uruguay: Artigas, 8 November 2013, L. Eggers et al. 837 (ICN).
Cypella fucata Ravenna, Wrightia 7(1): 18. 1981. Type: Brazil. Rio Grande do Sul: "Culta in Bonaria ex bulbis ad pedem collis ubi Gruta do Segredo est pr. Cacapava civit. Rio Grande do Sul Brasiliae", December 1965, P. Ravenna 500 (Holotype Herb. Ravenna, not seen). Lectotype: Brazil. Santa Catarina, mun. Lajes, Morro do Pinheiro Seco, 3 km east of Lajes, 4 February 1963, R. Reitz 6579 (HBR!) (Lectotype, here designated).

= Cypella osteniana Beauverd subsp. aurantiaca Roitman \& Castillo, Bol. Soc. Argent. Bot. 38: 337. 2003. Type: Argentina. Corrientes: "Dep. Monte Caseros, cercanías de Tres Bocas", 16 April 2003, G. Roitman \& G.M. Tourn s.n. (Holotype BAB 25088, not seen).

Figs. 3B, 9.

Herb 10-35 cm high; basal leaves linear, 0.06-0.3 $\mathrm{cm}$ wide. Synflorescence simple or composed of 2-5 pedunculate one-flowered rhipidia. Spathes lower valve $1.4-2.4 \mathrm{~cm}$ long, upper $2.8-4.5 \mathrm{~cm}$ long. Flowers dull orange, 25-47 mm diameter. Outer tepals pandurate, proximally concave, distally reclinate to reflexed, with dark red streaks proximally; inner tepals cuneate, assurgent proximally, then incurved and abruptly reclinate distally, proximally densely streaked with dark red, distally orange with light
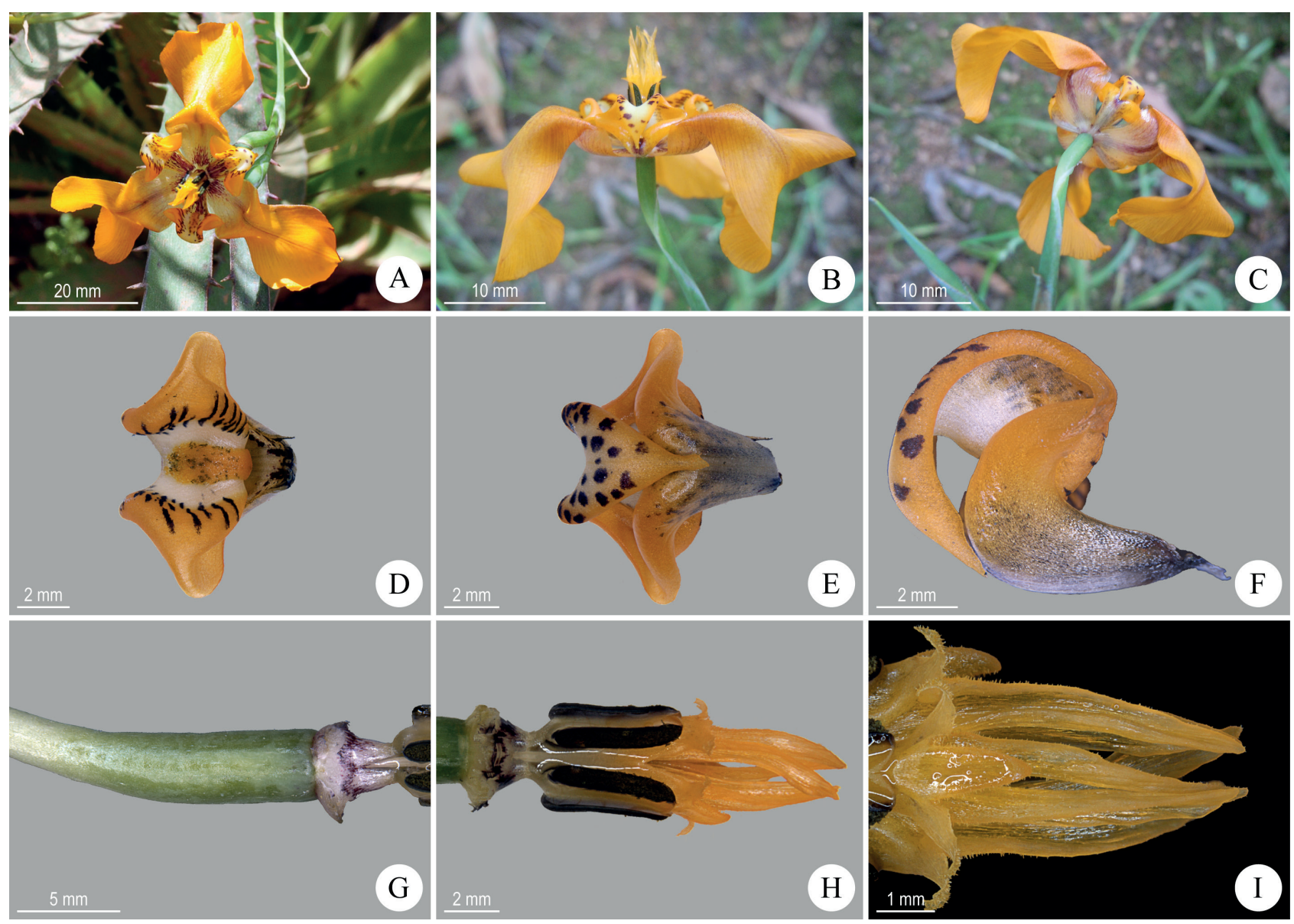

Figure 9. Cypella fucata. A-C. Flower. A. apical view B. lateral view C. basal view D-F. Inner tepal D. adaxial view E. abaxial view F. lateral view G. Ovary H. Stamens and style in lateral view I. Style crests and stigmatic replicatures. From: A-C. L. Eggers \& T.T. Souza-Chies 674 (ICN); D, E, H, I. T.L.S. Alves 204 (ICN); F, G. A. Silvério \& M.L. Gaeta s.n. (ICN 174144). 
yellow central portion and dense oblong orange area of elaiophores, laterally spotted to streaked with dark red and apically orange. Filaments connate basally for 0.1-0.2 $\mathrm{mm}$, ca. $1.8 \mathrm{~mm}$ long; anthers 3.6-5 mm long; connective whitish to pale orange-yellow, $0.8-1.4 \mathrm{~mm}$ wide; pollen ochraceous. Style whitish, 2.4-4 mm long; style arms yellowish to orange, $1.2-3 \mathrm{~mm}$ long, crests orange. Adaxial crests, 2, erect, 3.8-5.3 mm long, abaxial crest triangular, entire to lobed. Capsule obovoid-clavate.

Iconography: Deble \& Alves (2017a); Ravenna (1981b); Roitman \& Castillo (2003), as C. osteniana subsp. aurantiaca.

Distribution, habitat, and phenology: Cypella fucata occurs in the states of Rio Grande do Sul and Santa Catarina, in the Atlantic Rainforest and Pampa Biomes. The species also occurs in Argentina (Roitman \& Castillo 2003) and Uruguay (Ravenna 1981b; Roitman et al. 2008). It grows in grasslands, in populations usually formed by few individuals (Ravenna 1981b). Altitude records range from 71 to 950 $\mathrm{m}$ a.s.l. Flowering and fruiting individuals were collected from October to February, April and June.

Conservation status: The species can be considered as Nearly Threatened (NT), but categorization may change in the future, due to decline quality and/or loss of habitat caused by expansion of agricultural areas.

Notes: Collection R. Reitz 6579 (HBR) was examined by us and is here designated as lectotype of $C$. fucata, contrary to expressed by Deble \& Alves (2017a) which reported that the sample was not located at Herbarium HBR.

Cypella fucata is most similar to C. amplimaculata. However, $C$. fucata presents flowers dull orange usually smaller than the orange flowers of $C$. amplimaculata (25-47 $\mathrm{mm}$ vs. 45-60 mm diameter) and the outer tepals lack the conspicuous central stripe of the tepals of $C$. amplimaculata. Lastly, style crests of $C$. fucata are characteristic erect while style crests of $C$. amplimaculata are falcate inwards (Fig. 3B vs. 3A).

Specimens examined: Brazil. Rio Grande do Sul: Alegrete, 26 November 2013, L. Eggers et al. 877 (ICN); idem, 14 October 2014, T. Pastori et al. 122 (ICN); Caçapava do Sul, 1965, P. Ravenna 500 (MO); idem, 4 November 2011, A.M. Aita 97 (ICN); idem, 12 November 2014, T. Pastori et al. 169 (ICN); Campestre da Serra, 16 December 2012, T.L.S. Alves 258 (ICN); Capão do Leão, 31 October 2013, T. Pastori 101 (ICN); Ciríaco, 6 December 2013, L. Eggers \& O. Chauveau 888 (ICN); Guaíba, 26 October 2002, F.J.M. Caporal s.n. (ICN 180177); idem, 20 November 2004, L. Eggers \& T.T. Souza-Chies 80 (ICN); Lavras do Sul, 16 November 1992, C. Schlindwein s.n. (MPUC 13546); Manoel Viana, 19 April 2008, G. Bruisma 57 (ICN); Passo Fundo, 6 December 2013, L. Eggers \& O. Chauveau 887 (ICN); Pinheiro Machado, 20 November 2008, L. Eggers \& T.T. Souza-Chies 442 (ICN); idem, 11 November 2014, T. Pastori et al. 167 (ICN); Piratini, 21 November 2008, L. Eggers \& T.T. Souza-Chies 444 (ICN); Porto Alegre, Morro Santana, 9 November 2010, L. Eggers \& T.T. Souza-Chies 589 (ICN); idem, idem, 5 June 2012, A.
Silvério \& M.L. Gaeta s.n. (ICN 174144); Quaraí, 19 October 2003, G. Roitman et al. s.n. (BAA 25705); idem, 29 October 2008, R. Setubal \& I.I. Boldrini 739 (ICN); idem, 5 November 2010, E.M. Stiehl-Alves 10 (ICN); idem, 22 November 2012, L. Eggers et al. 790 (ICN); idem, 4 November 2015, T. Pastori \& R. Borges 197 (ICN); Rosário do Sul, 24 November 2013, L. Eggers et al. 868 (ICN); Uruguaiana, 6 November 2010, E.M. Stiehl-Alves 16 (ICN); idem, 6 November 2012, L. Eggers et al. 746 (ICN); Viamão, 10 November 2005, L. Eggers \& T.T. Souza-Chies 137 (ICN); idem, 18 December 2007, L. Eggers \& T.T. Souza-Chies 295 (ICN); idem, 1 November 2013, C.D. Inacio \& A.P. Schmitz 144 (ICN); Santa Catarina: Lajes, 15 January 1957, L.B. Smith \& R.M. Klein 10003 (MO, R).

Additional examined specimens: Uruguay: Cerro Largo, 13 November 2013, L. Eggers et al. 864 (ICN); Florida, 12 November 2013, L. Eggers et al. 860 (ICN); Paysandú, 9 November 2013, L. Eggers et al. 847 (ICN); Salto, 20 October 1961, J.C. Millot 535 (MVFA).

Cypella guttata Deble \& F.S. Alves, Phytotaxa 236(2): 105. 2015. Type: Uruguay. Artigas: Sarandy de Arapey, "cerca de $11 \mathrm{~km}$ nordeste da vila de Sarandy de Arapey", 22 October 2014, L.P. Deble et al. 14991 (Holotype MVFA, not seen; Isotypes SI, not found; ICN, not found).

Figs. 2F, 6B-C.

Herb 20-60 cm high; basal leaves linear, 0.5-1.2 cm wide. Synflorescence composed of 2-8 pedunculate oneflowered rhipidia. Spathes lower valve $1.4-1.9 \mathrm{~cm}$ long, upper 2.7-3.4 cm long. Flowers golden-yellow, 33-40 mm diameter. Outer tepals oblong, proximally concave, distally slightly patent to reclinate, densely covered by red spots proximally and with sparse spots at the base of the petal blade; inner tepals cuneate, assurgent proximally, then incurved and abruptly reclinate distally, proximally with red to reddish-brown stripes and spots, distally white-cream with yellow area of elaiophores spotted with reddish-brown, laterally golden-yellow streaked with reddish-brown and apically dull yellow. Filaments connate basally for $0.5-0.8$ $\mathrm{mm}, 4.5-5 \mathrm{~mm}$ long; anthers 5.5-6 mm long; connective dull yellow, 2-2.2 $\mathrm{mm}$ wide, pollen dark grey. Style yellow, 3-3.5 mm long; style arms yellow to golden-yellow, 4.5-5 $\mathrm{mm}$ long, crests golden-yellow. Adaxial crests, 2, erect, falcate inwards, 2.5-3.5 mm long, abaxial crest deltate, shortly bifid. Capsule obloid.

Iconography: Deble et al. (2015b).

Distribution, habitat, and phenology: Cypella guttata is distributed in the south-western region of the state of Rio Grande do Sul, in the Pampa Biome. The species also occurs in Uruguay. It is found in aquatic vegetation, growing in small rivers among rocks and in flooded river banks. Altitude records range from 200 to $380 \mathrm{~m}$ a.s.l. Flowering and fruiting individuals were collected in October, November and February (Deble et al. 2015b).

Conservation status: The species was categorized as Critically Endangered - CR, B1a,b(iii), B2a,b(iii), D by 
Deble et al. (2015b). There are no sufficient new elements to justify change of categorization, thus conservation status is accepted and maintained.

Notes: Cypella guttata can be distinguished from $C$. rivularis by the colour and size of flowers (golden yellow, 33-40 $\mathrm{mm}$ vs. bright yellow, 50-58 $\mathrm{mm}$ diameter), the width of filaments (linear to triangular vs. filiform) (Fig. $2 \mathrm{~F} v s$. $2 \mathrm{~J}$ ) and pollen colour (dark grey vs. yellow). Other species from hydrophytic environments can be distinguished by width of filaments (filiform in C. aquatilis) as well as by leaf width $(1.1-3.2 \mathrm{~cm}$ in $C$. aquatilis and $2-2.5 \mathrm{~cm}$ in $C$. herbertii subsp. herbertii).

Specimens examined: Brazil. Rio Grande do Sul: Quaraí, 5 November 2015, T. Pastori \& R. Borges 204 (ICN).

Cypella hauthalii (Kuntze) R.C.Foster subsp. minuticristata Chauveau \& L.Eggers, Phytotaxa 174(1): 33. 2014. Type: Brazil. Rio Grande do Sul: Soledade, propriedade particular do Sr. Waldemar Freitag, 2 November 2013, L. Eggers et al. 833 (Holotype ICN!; Isotypes MBM!, P!, SI!).

Figs. 3F, 6D-E.

Herb 11.4-20.6 cm high; basal leaves linear, 0.45-0.65 $\mathrm{cm}$ wide. Synflorescence $2-4$ pedunculate two-flowered rhipidia. Spathes lower valve 2.5-3.7 cm long, upper 3.8-5.4 $\mathrm{cm}$ long. Flowers white, subtly tinged with blue, $35-45 \mathrm{~mm}$ diameter. Outer tepals clawed, proximally erect, attenuate, distally slightly patent, with red-brown spots proximally, disposed sparsely or forming transversal stripes; inner tepals clawed proximally, then porrect, slightly incurved and reclinate distally, proximally spotted red-brown sometimes forming transversal stripes, distally whitish-blue with dense ovate, cordate to rhomboid yellow area of elaiophores, laterally golden yellow spotted with red-brown and apically bluish. Filaments free, 6-6.5 mm long; anthers 5-6 mm long; connective whitish to pale yellow, $0.4-0.8 \mathrm{~mm}$ wide; pollen yellow. Style whitish, 8.4-10 mm long; style arms whitish to pale blue, 3-3.5 $\mathrm{mm}$ long, crests whitish to pale blue. Adaxial crests, 2, erect, obsolete to $1 \mathrm{~mm}$ long, abaxial crest absent or rounded, obsolete. Capsule obovoid-truncate.

Iconography: Chauveau et al. (2014).

Distribution, habitat, and phenology: Cypella hauthalii subsp. minuticristata occurs in the central region of the state of Rio Grande do Sul in the northern limit of the Pampa Biome, and in the Atlantic Rainforest Biome. It grows in grassland vegetation, forming large populations. Altitude records range from 308 to 534 $\mathrm{m}$ a.s.l. (Chauveau et al. 2014). Flowering and fruiting individuals were recorded in October, November and December (cultivated material).

Conservation status: The species was categorized as Critically Endangered - CR, B1a,b(iii) by Chauveau et al. (2014). There are no additional collections or other elements to justify new categorization, thus conservation status is maintained.
Notes: Cypella hauthalii subsp. minuticristata presents white flowers, subtly tinged with blue. The clawed outer tepals, proximally erect and attenuate differentiate this species from $C$. discolor and $C$. luteogibbosa, both with pandurate outer tepals. Adaxial crests obsolete to $1 \mathrm{~mm}$ long also distinguish this taxon from $C$. hauthalii subsp. opalina and, among other traits, from $C$. discolor and $C$. luteogibbosa (Fig. 3F vs. 3G, 3E, 3H, respectively).

Specimens examined: Brazil. Rio Grande do Sul: Salto do Jacuí, 20 October 2012, L. Eggers et al. 727 (ICN); idem, 19 October 2013, L. Eggers et al. 827 (ICN).

Cypella hauthalii (Kuntze) R.C.Foster subsp. opalina Ravenna, Wrightia 7(1): 21. 1981. Type: Argentina. Corrientes: "Culta in Santiago ex bulbo ad ripas fluminis Uruguay pr. Garruchos” October 1980, P. Ravenna 3300 (Holotype Herb. Ravenna, not seen). Lectotype: Argentina. Corrientes: Departamento Santo Tomé, Garruchos, Estancia San Juan Bautista, costa del rio Uruguay, 20 September 1974, A. Krapovickas et al. 25807 (CTES!) (Lectotype, here designated).

Figs. 3G, 10.

Herb 6.3-22 cm high; basal leaves linear, 0.4-0.6 cm wide. Synflorescence composed of 2-6 pedunculate twoflowered rhipidia. Spathes lower valve 2-3.1 cm long, upper $2.9-4.2 \mathrm{~cm}$ long. Flowers white, subtly tinged with yellow, 30-48 mm diameter. Outer tepals clawed, proximally erect, attenuate, distally slightly patent, with red-brown spots proximally, disposed sparsely or forming transversal stripes, with a longitudinal yellow spot just above; inner tepals clawed proximally, then porrect, incurved and slightly reclinate distally, proximally spotted red-brown sometimes forming transversal stripes, distally white to whitish-blue with dense large triangular to rhomboid yellow area of elaiophores, laterally golden yellow spotted with red-brown and apically white to whitish-blue. Filaments free, $4.5-5 \mathrm{~mm}$ long; anthers 5-6 $\mathrm{mm}$ long; connective beige to pale yellow, $0.7-0.8 \mathrm{~mm}$ wide; pollen yellow to ochre. Style whitish with red-brown to purplish spots, 6-7 mm long; style arms whitish, 3.5-5.5 mm long, crests white to white-bluish. Adaxial crests, 2, erect, slightly falcate inwards, 3.7-4.5 $\mathrm{mm}$ long, abaxial crest elliptic. Capsule obovoid-truncate.

Distribution, habitat, and phenology: Cypella hauthalii subsp. opalina is distributed in the north-western region of the state of Rio Grande do Sul, in the Pampa Biome. It occurs also in Argentina (Ravenna 1981b; Roitman et al. 2008). It grows in grasslands, sometimes in anthropized areas along rural roadsides, forming dense populations. Altitude records range from 99 to $355 \mathrm{~m}$ a.s.l. Flowering and fruiting occurs from September to December.

Conservation status: Cypella hauthalii subsp. opalina was categorized as Endangered (EN, B1a,b(ii)) in the evaluation of threatened flora species of Rio Grande do Sul state (Rio Grande do Sul 2014). Up-to-date analysis of conservation status of the species qualify it as Nearly 
Threatened (NT) since, although Extent of Occurrence and Area of Occupancy values may allow categorization, conditions of subcriteria were not fulfilled.

Notes: Plant material indicated at the original description of the species included the type at Herbarium Ravenna, one collection of A. Krapovickas et al. 25807 (CORD) and one collection of cultivated plants from Argentina. Due to the unaccessibility of types at Herbarium Ravenna and since the paratype at CORD was not localized, the isoparatype $A$. Krapovickas et al. 25807 (CTES) was selected as lectotype.

Cypella hauthalii subsp. opalina presents white flowers, subtly tinged with yellow. It differs from C. hauthalii subsp. minuticristata by the adaxial crests 3.7-4.5 mm long (vs. obsolete to $1 \mathrm{~mm}$ long) (Fig. $3 \mathrm{G}$ vs. 3F). From C. discolor and $C$. luteogibbosa, it can be segregated by the clawed other tepals, proximally erect and attenuate ( $v s$. pandurate in both species).

Specimens examined: Brazil. Rio Grande do Sul: Bossoroca, 17 October 2013, E.M. Stiehl-Alves et al. 42 (ICN); Itacurubi, 17 October 2013, E.M. Stiehl-Alves et al. 45 (ICN); Manuel Viana, 14 October 2014, T. Pastori et al. 128 (ICN); Santo Antônio das Missões, 14 October 2005, L. Eggers \& T.T. Souza-Chies 113 (ICN); idem, 6 December 2007, I.I.
Boldrini et al. 1477 (ICN); idem, 29 October 2009, L. Eggers \& T.T. Souza-Chies 541 (ICN); idem, 18 October 2013, E.M. Stiehl-Alves et al. 50 (ICN); São Borja, 8 November 2012, L. Eggers et al. 764 (ICN); São Nicolau, 18 October 2013, E.M. Stiehl-Alves et al. 51 (ICN); Tupanciretã, 9 November 1946, A.R. Schultz 501 (ICN); Unistalda, 30 October 2009, L. Eggers \& T.T. Souza-Chies 553 (ICN).

Additional examined specimens: Argentina: Corrientes, Santo Tomé, 7 December 1997, M.E. Múlgura de Romero et al. 1585 (SI); idem, 18 November 2003, G.E. Barboza et al. 814 (CORD, ICN); idem, 10 October 2006, G. Roitman s.n. (BAA 25704); Misiones, Apóstoles, 18 September 2000, M.E. Múlgura de Romero et al. 2016 (SI).

Cypella herbertii (Lindl.) Herb. subsp. brevicristata Ravenna, Bol. Soc. Argent. Bot. 10(4): 312. 1965. Type: Uruguay. Artigas: "Culta in Bonaria ex bulbis collectis in septentrione Uruguay in proximis locibus urbi Artigas, in campis inter fruticis", 1 November 1959, P. Ravenna s.n. (Holotype Herb. Ravenna, not seen). Neotype: Uruguay. Artigas: Arroyo Pintadito, 6 December 2015, L.P. Deble \& F.S. Alves 15996 (designated by Deble \& Alves 2017b) (Neotype SI, not found; Isoneotype MVFA, not seen).
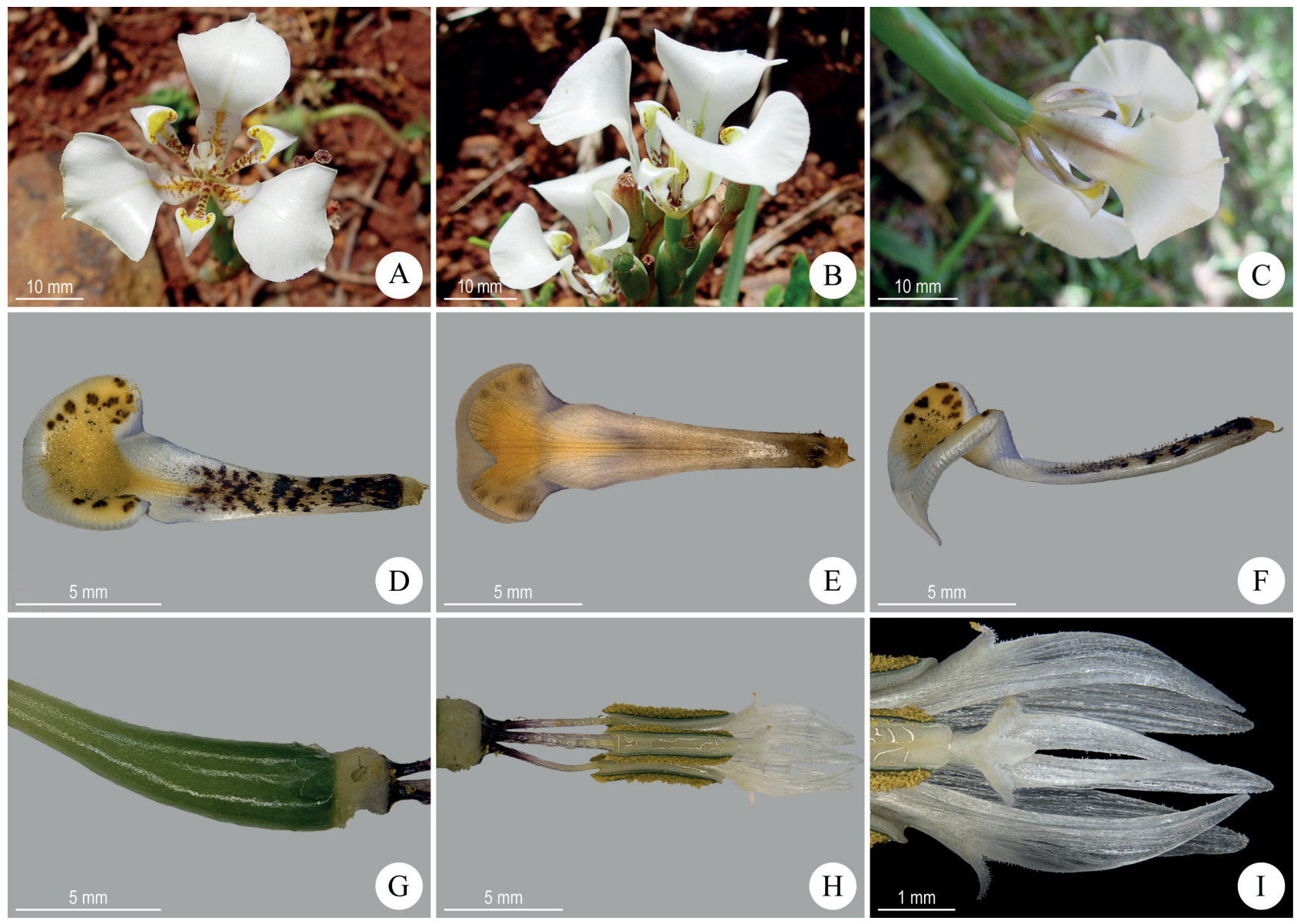

Figure 10. Cypella hauthalii subsp. opalina. A-C. Flower. A. apical view B. lateral view C. basal view D-F. Inner tepal D. adaxial view E. abaxial view F. lateral view G. Ovary H. Stamens and style in lateral view I. Style crests and stigmatic replicatures. From: L. Eggers \& T.T. Souza-Chies 541 (ICN). 
Figs. 2G, 11A-B.

Herb 30-70 cm high; basal leaves linear to narrowly elliptic, $0.4-1.5 \mathrm{~cm}$ wide. Synflorescence 2-6 pedunculate one-flowered rhipidia. Spathes lower valve $1.6-1.9 \mathrm{~cm}$ long, upper 2.2-3.4 cm long. Flowers yellow, 34-40 mm diameter. Outer tepals oblong to spathulate, proximally concave, distally patent to slightly reclinate, with diminutive red-brown spots proximally and a conspicuous brown central stripe in the descending curvature and sometimes in the concave portion; inner tepals cuneate, assurgent proximally, then incurved and abruptly reclinate distally, proximally sparse or densely streaked with red-brown, distally yellow with white-cream central portion and yellow area of elaiophores, laterally spotted with reddish-brown and apically yellow. Filaments connate basaly for 1.5-2.8 $\mathrm{mm}, 3-3.5 \mathrm{~mm}$ long, anthers 6-7 mm long; connective dark purplish to red-brown, 3-3.6 mm wide; pollen ochraceous. Style yellow, 6-6.7 mm long; style arms proximally yellow, distally stained red-brown, 2.3-2.8 mm long, crests proximally stained red-brown, distally yellow to ochre. Adaxial crests, 2, erect, falcate inwards, 0.5-1 mm long, abaxial crest deltate. Capsule obovoid-obloid.

Iconography: Deble \& Alves (2017b).

Distribution, habitat, and phenology: Cypella herbertii subsp. brevicristata is distributed in the southwestern region of the state of Rio Grande do Sul, in the Pampa Biome. It also occurs in Uruguay (Ravenna 1965; Roitman et al. 2008; Deble \& Alves 2017b). It grows in humid to well drained grasslands, with altitude records ranging from 94 to $163 \mathrm{~m}$ a.s.l. Flowering and fruiting occurs from October to January.

Conservation status: Deble \& Alves (2017b) classified the species as Endangered - EN, B1, B2a,b(iii). Taking into account the additional collections here presented, the species was re-evaluated for conservation status. Categorization is maintained as Endangered, however criteria B1 was removed from the original classification, since the species did not meet the criteria. The new threatened category is EN, B2a,b(iii).

Notes: Both subspecies of $C$. herbertii have flowers with a conspicuous brown central stripe in the descending curvature of the outer tepals, dark coloured connective and style arms distally and crests proximally dark coloured. However, C. herbertii subsp. herbertii exhibits orange flowers and C. herbertii subsp. brevicristata, yellow flowers. Also, size of adaxial crests can be observed to differentiate both subspecies, being from $0.5-1 \mathrm{~mm}$ long in C. herbertii subsp. brevicristata, and 1.8-4 $\mathrm{mm}$ long in C. herbertii subsp. herbertii (Fig. 2G vs. 3C).

Specimens examined: Brazil. Rio Grande do Sul: Quaraí, 27 October 2011, A.M. Aita 79 (ICN); São Borja, 30 October 2009, L. Eggers \& T.T. Souza-Chies 547 (ICN); Uruguaiana, 4 January 2012, T. Guimarães \& L. Dal Ri 5 (ICN).

Additional examined specimens: Uruguay: Artigas, 8 November 2013, L. Eggers et al. 839 (ICN); Paysandú, 9
November 2013, L. Eggers et al. 845 (ICN); Rio Negro, 10 November 2013, L. Eggers et al. 848 (ICN); Salto, 8 November 2013, L. Eggers et al. 841 (ICN).

Cypella herbertii (Lindl.) Herb. subsp. herbertii, Curtis's Bot. Mag. 53: t. 2637. 1826.

$\equiv$ Moraea herbertii Lindl., Bot. Reg. 11: t. 949.1826 (1825). Lectotype: Original plate of Moraea herbertii published at Botanical Register 11: t. 949. 1826 (1825). (Lectotype, here designated). Epitype: Argentina. Buenos Aires, s.d., J. Tweedie 765, second plant from right to left (K000523855!) (Epitype, here designated).

= Cypella catharinensis Ravenna, Onira 10(13): 39. 2005. Type: Brazil. Santa Catarina: São Joaquim, "camino frente al Horto de Floricultura”, 14 December 1967, A. Lourteig 2180 (Holotype BAB [image!]; Isotypes CTES!, R [image!], P!).

Figs. 3C, 12.

Herb 30-100 cm high; basal leaves linear to narrowly elliptic, 2-2.5 cm wide. Synflorescence 3 to more than 10 pedunculate one-flowered rhipidia. Spathes lower valve 1.5$2.5 \mathrm{~cm}$ long, upper $2.8-3.8 \mathrm{~cm}$ long. Flowers orange, 40-70 $\mathrm{mm}$ diameter. Outer tepals spathulate, proximally concave, distally patent to reclinate, with diminutive red-brown to dark purple spots proximally and a conspicuous red-brown central stripe in the descending curvature and in the concave portion; inner tepals cuneate, assurgent proximally, then incurved and abruptly reclinate distally, proximally densely streaked with red-brown to dark purple, distally orange with white central portion and yellow area of elaiophores, laterally streaked with red-brown and apically orange. Filaments connate basaly for 1.4-2.8 mm, 2.8-4 mm long, anthers 4.5-6.8 mm long; connective dark red-brown to dark purple, $1.5-1.8 \mathrm{~mm}$ wide; pollen yellowish green. Style whitish, 3-4.5 mm long; style arms proximally whitish with purple spots, distally red brown to dark purple, 2.3-5.5 mm long, crests proximally stained red-brown to purple, distally yellow ochre. Adaxial crests, 2, erect, falcate inwards, 1.8-4 mm long, abaxial crest triangular, entire to slightly lobed. Capsule obovoid-obloid.

Iconography: Deble \& Alves (2017b); Eggers (2008); Herbert (1825), as Tigridia herbertii; Lawrence (1957); Lindley (1826 [1825]), as Moraea herberti; Maund (1840); Plachon (1849); Ravenna (1968); Sweet (1831).

Distribution, habitat, and phenology: Cypella herbertii subsp. herbertii occurs in the states of Paraná, Rio Grande do Sul and Santa Catarina, in the Atlantic Rainforest and Pampa Biomes. It is also distributed in Argentina and Uruguay (Ravenna 1968; Roitman et al. 2008). The species grows in grasslands, mostly associated with humid soils, and frequently form dense populations. Altitude records range from 54 to $1133 \mathrm{~m}$ a.s.l. Flowering and fruiting individuals were collected from October to April.

Conservation status: The species is classified as Nearly Threatened (NT), but threatened category may change in the future, due to decline quality and/or loss of habitat caused by drainage or expansion of agriculture. 

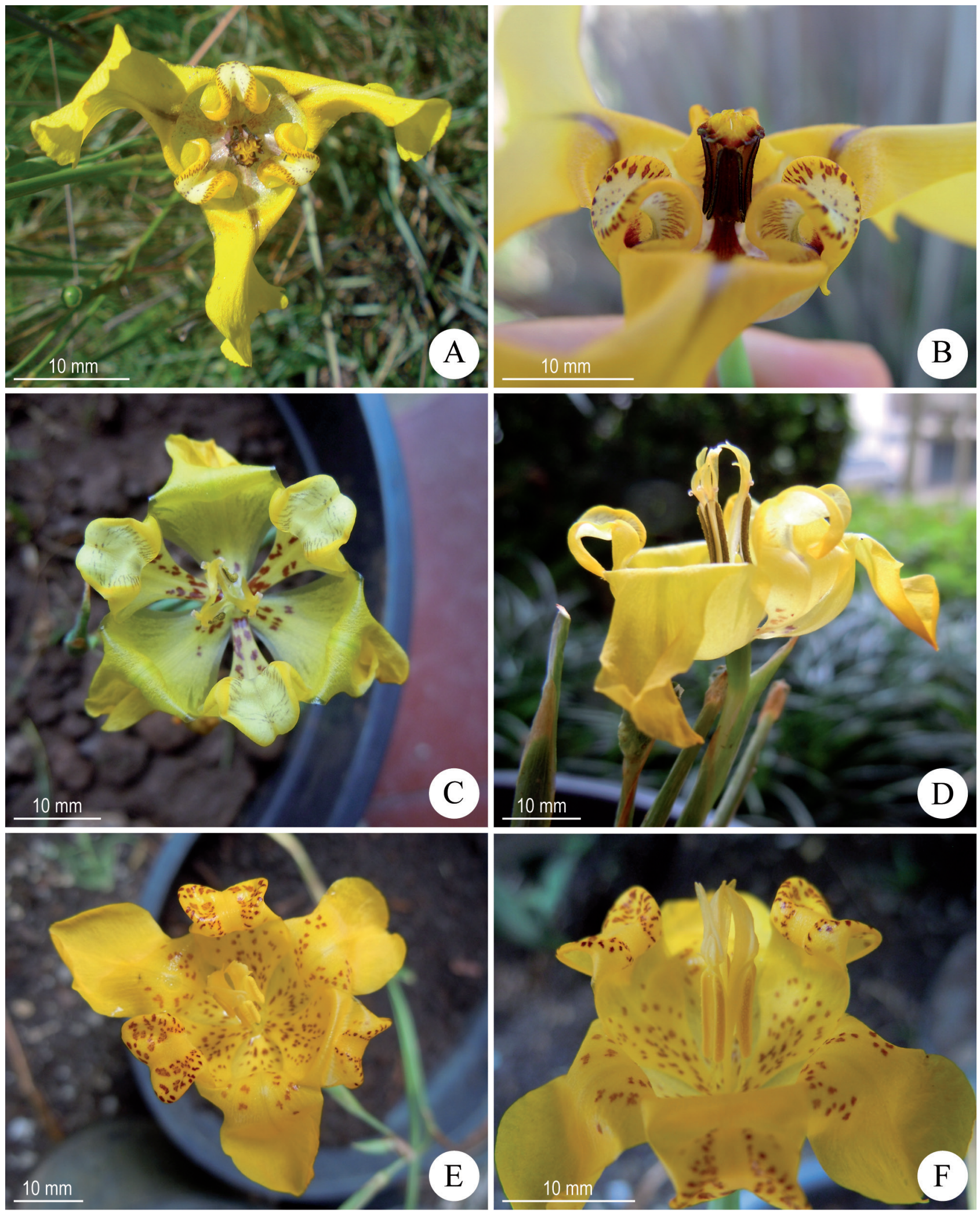

Figure 11. Flowers of Cypella spp. A-B. Cypella herbertii subsp. brevicristata. A. apical view B. stamens and style in lateral view. C-D. C. ravenniana. C. apical view D. lateral view E-F. C. rivularis. E. apical view F. apical inclinate view. A. T. Guimarães \& L. Dal Ri 5 (ICN) (photo L. Dal Ri); B. L. Eggers \& T.T. Souza-Chies 547 (ICN); C-D. T. Pastori et al. 142 (ICN); E-F. L. Eggers et al. 800 (ICN). 
Notes: Cypella herbertii is a new combination based on Moraea herbertii (Lindley 1826 [1825]), described and illustrated in the ancient horticultural magazine The Botanical Register. The botanist William Herbert (1825) also published the binomial Tigridia herbertii, reporting that the epithet followed the proposition of Lindley, as a tribute to the honorable and reverend George Herbert, Rector of Burghclere, Hampshire. The species was cultivated from seeds imported from Buenos Aires. Since no original sample of $M$. herbertii has been found, the plate of the species at the original publication is here selected to be the lectotype. Also, we designate one plant at the collection of J. Tweedie 765 at Herbarium K (K000523855) as epitype. Although without bulb and basal leaves, this sample presents a relatively well preserved flower and marginal annotations related to the name.

Cypella catharinensis is here included as synonym of Cypella herbertii subsp. herbertii, as indicated by Roitman et al. (2008). This taxon was described by Ravenna (2005) based on a single dried specimen (A. Lourteig 2180 of BAB Herbarium) and was segregated from $C$. herbertii by preseting filaments $3.5-4 \mathrm{~mm}$ long, basally incrassate and connate, and adaxial crests ca. $1.5 \mathrm{~mm}$ long. Anthers were reported to have $4 \mathrm{~mm}$ and stated to be "small, nearly as long as the filaments". After synonymization (Roitman et al. 2008), the species was revalidated by Ravenna (2009), who asserted that $C$. catharinensis presented "substantial differences in androecium and gynoecium" from $C$. herbertii. However, only subjective justifications such as "free and narrow" filaments, and "rather shorter" crests than $C$. herbertii were presented.

Field expedition carried out to the type locality did not succeed to recover other specimens of $C$. catharinensis and also no additional exsiccates were retrieved in herbaria revision. Furthermore, analysis and measurements performed in the isotype A. Lourteig 2180 at Herbarium $\mathrm{P}$ showed incongruences with the original description. Although filaments were confirmed to be 3.5-4 mm long, flower width was $41 \mathrm{~mm}$ (vs. $27 \mathrm{~mm}$ ) and anthers were 5-6 mm long (vs. $4 \mathrm{~mm}$ ). Other flower measurements were not possible to be accomplished. Fusion of filaments was not possible to be determined with certitude, however incoherent information on original description ("filaments basally incrassate and connate", Ravenna 2005) and on Ravenna (2009) ("filaments free and narrow") does not allow to well characterize the taxon. Due to the absence of clear morphological differences between $C$. catharinensis and C. herbertii, as well to the
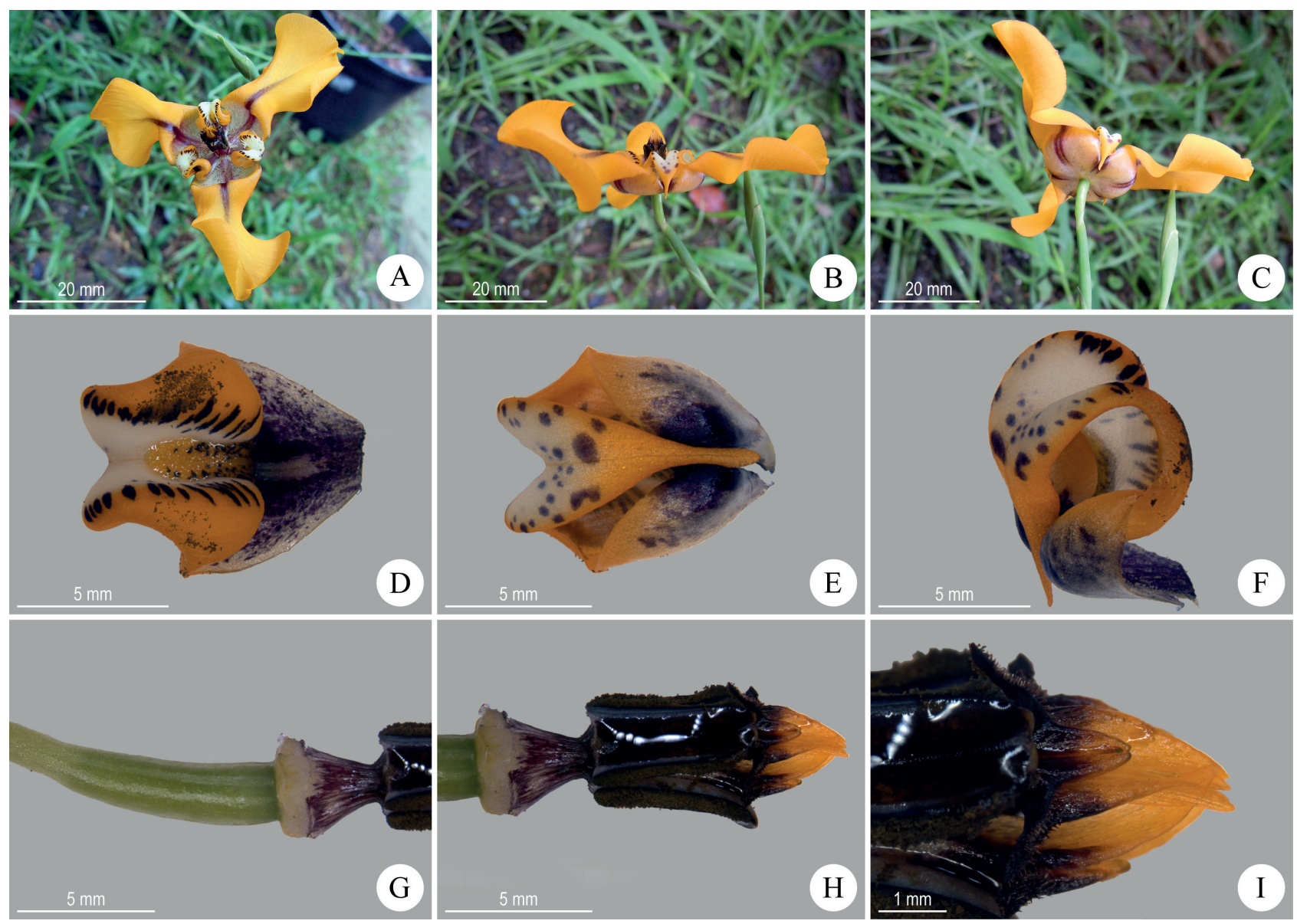

Figure 12. Cypella herbertii subsp. herbertii. A-C. Flower. A. apical view B. lateral view C. basal view D-F. Inner tepal D. adaxial view E. abaxial view F. lateral view G. Ovary H. Stamens and style in lateral view I. Style crests and stigmatic replicatures. From: A.M. Aita 77 (ICN). 
lack of other evidences that confirm the existence of the first species, we agree with the synonymization of C. catharinensis.

Cypella herbertii subsp. herbertii can be segregated from C. herbertii subsp. brevicristata by the flower colour (orange vs. yellow) and size of the crests (adaxial crests 1.8-4 mm vs. $0.5-1 \mathrm{~mm}$ ) (Fig. 3C vs. 2G). From other orange flowered taxa, Cypella herbertii subsp. herbertii can be distinguished by the wide leaves $(2-2.5 \mathrm{~cm})$; flowers with a conspicuous red-brown central stripe in the descending curvature and in the concave portion of the outer tepals; filaments linear to triangular, connate basaly for $1.4-2.8 \mathrm{~mm}$; connective dark red-brown to dark purple, 1.5-1.8 mm wide; style arms distally red brown to dark purple and crests proximally stained red-brown to purple.

Specimens examined: Brazil. Paraná: Curitiba, Bacaxiri, 10 December 1969, G. Hatschbach 23192 (MO, NY); São José dos Pinhais, 3 November 1914, P.K.H. Dusén 15848 (US); Rio Grande do Sul: Alegrete, 23 November 2012, L. Eggers et al. 802 (ICN); Caçapava do Sul, 17 November 2002, V. Kinupp \& J.A. Jarenkow 2485 (ICN); Dom Pedrito, 21 December 2012, L. Eggers et al. 787 (ICN); Itaqui, 16 October 1989, A. Castillo et al. s.n. (BAA 21619); Pedro Osório, Passo do Ricardo, 4 November 1961, G.F.J. Pabst et al. 6586 (R); Porto Alegre, October 1944, B. Rambo s.n. (PACA 26929); idem, 16 October 1945, B. Rambo s.n. (PACA 29296); Quaraí, 14 December 1989, C. Schlindwein s.n. (MPUC 13543); Rosário do Sul, 23 November 2012, L. Eggers et al. 804 (ICN); Santana do Livramento, 3 November 1995, J.R. Stehmann et al. 2005 (UEC); idem, 9 December 1995, C. Schlindwein 760 (MPUC 13544); São Gabriel, 13 October 1971, J.C. Lindeman et al. s.n. (ICN 8335); idem, January 1944, B. Rambo s.n. (PACA 25599); Uruguaiana, 3 November 1984, A.L.B. Salles s.n. (MPUC 18690); idem, 8 October 1985, M. Gomes s.n. (MPUC 18680); Veranópolis, 24 December 1987, N. Silveira 5554 (HAS); Santa Catarina: São Joaquim, 12 February 1954, J. Mattos 1057a (HAS); idem, 18 February 1954, J. Mattos 1612 (HAS); idem, 30 January 1957, J. Mattos 4429 (HAS); idem, 16 January 1957, L.B. Smith \& R. Reitz 10189 (R); idem, December 1963, J. Mattos 11299 (HAS).

Additional examined specimens: Argentina: Buenos Aires, 1 February 1951, O. Boelcke 3287 (BAA); idem, 25 October 1925, A. Burkart 15 (BAA); idem, November 1962, H.A. Fabris 3209 (LP); idem, 1 November 1885, C. Osten 2572 (MVM); idem, 19 November 1962, C. Calderon s.n. (BAA 2605); idem, camino a San Vicente, 28 November 1974, E.M. Zardini 587 (LP); idem, 12 November 1899, K. Bettfreund s.n. (T. Stuckert 7657) (CORD); idem, 11 November 1939, J. Basañao s.n. (SI 095717); idem, Barracas al Sud, 12 March 1902, S. Venturi 91 (CORD); idem, Campana, 8 December 2003, J. Hurrell et al. 5384 (SI); idem, Castelar, 20 November 1953, J.H. Hunziker 6301 (CORD); idem, Delta, 29 January 1939, E. Nicora 2125 (SI); idem, Escobar, 31 October 2004, J. Hurrell et al. 5725 (SI); idem, General Pueyrredón, 3
December 1946, A. L. Cabrera 10340 (LP, SI); idem, La Plata, 9 February 1999, Delucchi 2150 (LP); idem, Las Palmas, January 1964, H.A. Fabris 4979 (LP); idem, Lomas, 21 November 1940, E. Nicora 2821 (SI); idem, Magdalena, 27 October 2007, J. Hurrell et al. 6577 (SI); idem, idem, 3 December 2009, O. Morrone et M.A. Chemisquy 6268 (SI); idem, Mar del Plata, 1 January 1935, O.T. Solbrig 1030 (LP); idem, Palermo, s.d., M. Canónica s.n. (SI); idem, idem, 1897, C.M. Hicken s.n. (SI 25754); idem, idem, December 1907, J.C. Masquijo s.n. (SI 25759); idem, Punta Lara, 28 October 1939, A.L. Cabrera 5374 (SI); idem, Quilmes, 4 January 1913, D. Rodriguez 169 (SI); idem, San Fernando, January 1901, T. Stuckert 11610 (CORD); idem, idem, 15 November 1974, D. Medan 80 (BAA); idem, San Vicente, 21 April 2009, S.S. Aliscioni et al. 827 (BAA); idem, Sierras del Tandil, s.d., D. Abiatti 4331 (LP); idem, idem, 19 November 1970, J. Frangi 112 (LP); idem, Tandil, 21 January 1900, C.M. Hicken s.n. (SI 25757); idem, idem, 20 January 1950, G. Dawson 3022 (LP); idem, Tapalqué, December 1886, C. Osten 2729 (MVM); idem, Tigre, December 1930, A. Burkart 3332 (SI); idem, idem, Delta do Paraná, 26 December 1931, A. Burkart 4545 (SI); idem, idem, February 1938, A.T. Hunziker 903 (CORD); idem, idem, February 1942, A.T. Hunziker 3401(CORD); idem, via del Pacífico, November 1919, C.M. Hicken s.n. (SI 37885); Córdoba, Cruz del Eje, February 1902, A. Fuchs s.n. (T. Stuckert 11323) (CORD); idem, Leones, 19 December 1965, W. Partridge s.n. (CORD 11774); idem, idem, 30 November 1965, W. Partridge s.n. (CORD 11775); idem, Marcos Juarez, 28 December 1904, T. Stuckert 14777 (CORD 62601); Corrientes, Empedrado, 10 January 1975, T.M. Pedersen 10859 (CTES); idem, Mercedes, 17 October 1975, A. Schinini et al. 11750 (CTES); idem, Monte Caseros, 2 November 1950, E. Nicora 5633 (SI); idem, Passo de Los Libres, 13 December 2000, S.S. Denham 144 (SI); idem, San Martin, 30 October 1971, A. Krapovickas et al. 20150 (CTES); idem, idem, 30 October 1971, A. Krapovickas et al. 20179 (CTES); idem, idem, 16 February 1976, A. Krapovickas et al. 29221 (CTES); idem, idem, 16 February 1976, A. Krapovickas et al. 29244 (CTES); idem, idem, 1 November 2011, A. Schinini et al. 35702 (CTES); idem, Santo Tomé, Garruchos, 10 October 1969, T.M. Pedersen 9231 (SI); idem, Yapeyú, 11 November 1936, A. Burkart 8012 (SI); Entre Rios, Colón, 12 February 1931, A. Castellanos s.n. (BA 31-1001bis); idem, idem, 17 November 2013, A.A. Cocucci \& A.N. Sérsic 5332 (CORD); idem, idem, 18 November 2013, A.A. Cocucci \& A.N. Sérsic 5425 (CORD); idem, Concepcion del Uruguay, 1875, P.G. Lorentz 136 (CORD); idem, idem, 11 November 1875, P.G. Lorentz 488 (CORD); idem, Concordia, 18 November 2003, A.A. Cocucci et al. 3011 (CORD); idem, Gualeguay, s.d., M.M. Job s.n. (LP 22627); idem, idem, 24 February 2003, J. Hurrell et al. 5091 (SI); idem, Paraná, 2 December 2002, G. Barboza et al. 345 (CORD); idem, Uruguay, 9 December 2004, J. Pensiero 6838 (SI); Santa Fé, Castellanos, 14 November 1988, J. Pensiero \& Faurie 3336 (CORD); idem, Las Colonias, 25 November 1991, J. Pensiero et al. 3849 (SI); idem, San 
Geronimo Norte, 14 January 1941, C.C. Hosseus 8 (CORD). Uruguay: Artigas, Cuarem, 29 October 1902, M.B. Berro 2696 (MVFA); Cerro Largo, January 1926, W. Herter s.n. (MVM 18525); idem, 23 December 1961, D. Legrand 4794 (MVM); Colonia, Colonia Suiza, 26 December 1915, M.B. Berro 8419 (MVFA); Maldonado, 9 January 1999, A.A. Cocucci \& A.N. Sérsic 1100 (CORD); idem, 19 December 1931, C. Osten 22354 (MVM); Minas, 22 March 1924, W. Herter s.n. (MVM 18526); Montevideo, 1877, J. Arechavaleta 26 (MVM); idem, 1870, J.E. Gibert 499 (MVM); idem, 1951, J. Mattos 1782 (HAS); Paysandu, Arroio Negro, 12 November 1937, B. Rosengurtt 2274 (MVFA, MVM); Rio Negro, Frey Bentos, November 1914, M.B. Berro 7622 (MVFA); Rivera, 18 December 1945, D. Legrand 4101 (MVM); Rocha, 19 March 1938, D. Legrand 1419 (MVM); Soriano, 30 October 1898, M.B. Berro 110 (MVFA); idem, 7 November 1894, C. Osten 3178 (MVM).

Cypella luteogibbosa Deble, Phytotaxa 71: 60. 2012. Type: Brazil. Rio Grande do Sul: Quaraí, $28 \mathrm{~km}$ ao sul do trevo para o Passo da Guarda, 19 October 2010, L.P. Deble \& A.S. Oliveira-Deble 10265 (Holotype PACA [image!]).

Figs. 3H, 13.
Herb 15-35 cm high; basal leaves linear, 0.2-0.5 cm wide. Synflorescence of 2-3 pedunculate one-flowered rhipidia. Spathes lower valve $1.4-2.2 \mathrm{~cm}$ long, upper $2.5-3 \mathrm{~cm}$ long. Flowers predominantely white with purplish-brown venation, 28-36 mm diameter. Outer tepals pandurate, proximally concave, distally reflexed, with a faint central yellowish area of elaiophores at the constricted region, sometimes longitudinal stained to the distal end of the tepal blade; inner tepals cuneate, assurgent proximally, then incurved and abruptly reclinate distally, proximally striated purplish-brown to dark purple, distally with yellow central area of elaiophores, laterally dotted purplish-brown to dark purple and apically white. Filaments free, 2-2.4 mm long; anthers 3.2-4.5 mm long; connective white to cream, $0.6-0.9 \mathrm{~mm}$ wide; pollen light blue. Style white, 1-2 mm long; style arms white, 3-4 mm long, crests white. Adaxial crests, 2, erect to divergent, slightly falcate inwards, $3.4-5 \mathrm{~mm}$ long, abaxial crest bilobed. Capsule obovoid-obloid.

Iconography: Deble et al. (2012c).

Distribution, habitat, and phenology: Cypella luteogibbosa occurs in the south-western region of the state of Rio Grande do Sul, in the Pampa Biome, and in Uruguay.
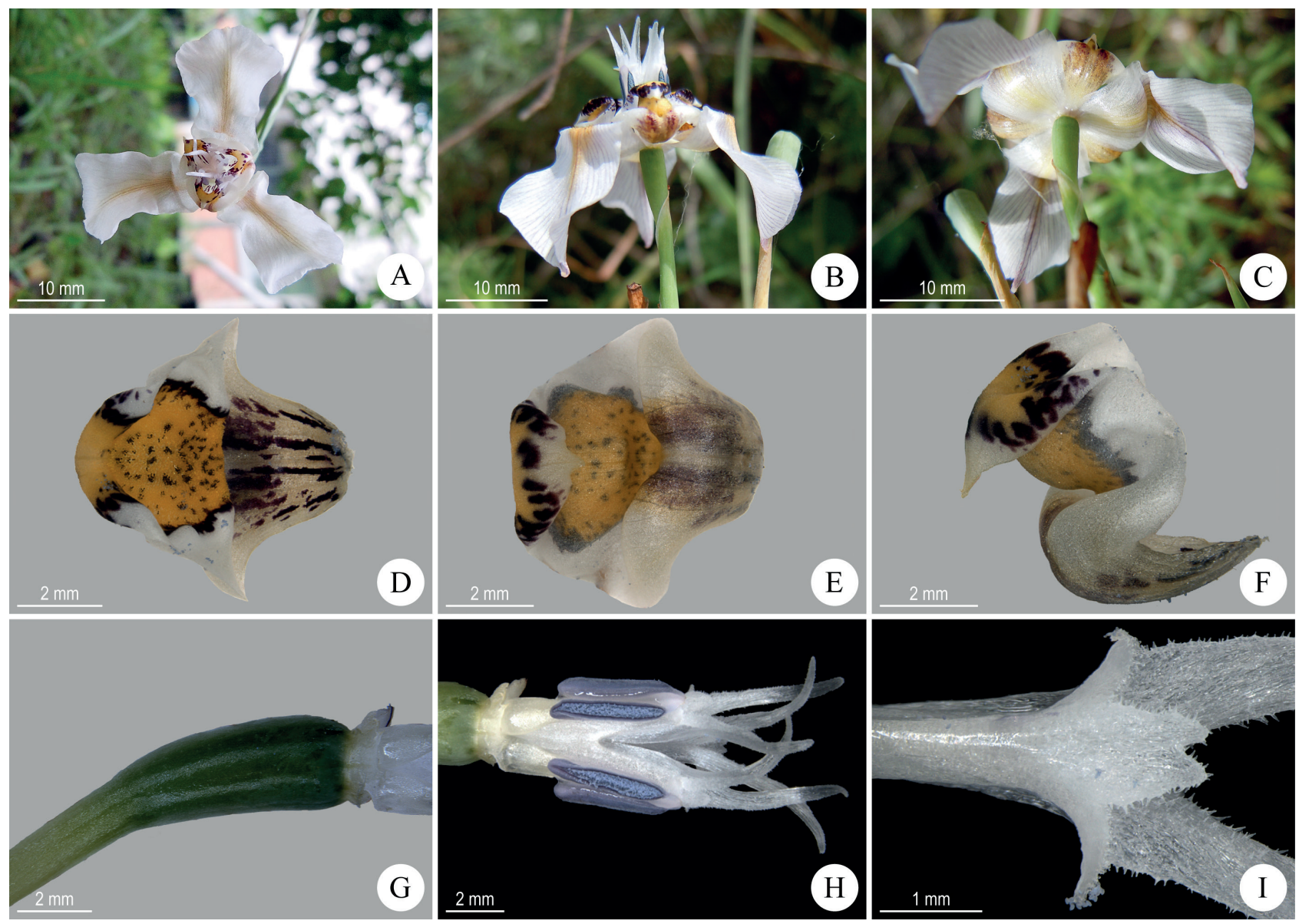

Figure 13. Cypella luteogibbosa. A-C. Flower. A. apical view B. lateral view C. basal view D-F. Inner tepal D. adaxial view E. abaxial view F. lateral view G. Ovary H. Stamens and style in lateral view I. Style crests and stigmatic replicatures. From: L. Eggers \& O. Chauveau 711 (ICN). 
It grows in stony grasslands, in altitude records of about $150 \mathrm{~m}$ a.s.l. Flowering and fruiting occurs from October to December.

Conservation status: Deble et al. (2012c) classified the species as Critically Endangered - CR, B2a,b(iii), D. The species was re-evaluated taking into account additional collections and is here classified as Endangered - EN, B1, B2a,b(iii).

Notes: Cypella luteogibbosa can be differentiated from other white flowered Cypella by the aspect of the distal portion of the outer tepals, which is reflexed (vs. patent to reclinate in $C$. discolor, and slightly patent in both subspecies of $C$. hauthalii). Also, it presents shorter filaments (2-2.4 $\mathrm{mm}$ vs. up to $4.5 \mathrm{~mm}$ ) and anthers (3.2 to $3.5 \mathrm{~mm}$ vs. up to $5 \mathrm{~mm}$ ) than $C$. discolor and both subspecies of $C$. hauthalii (Fig. 3H vs. 3F, 3G, 3E).

Specimens examined: Brazil. Rio Grande do Sul: Quaraí, 16 December 2010, L.P. Deble \& A.S. Oliveira-Deble 11604 (PACA); idem, 22 November 2012, L.Eggers et al. 791 (ICN); idem, 14 November 2013, E.M. Stiehl-Alves et al. 96 (ICN); Uruguaiana, 5 November 2010, A.M. Aita 107 (ICN).

Additional examined specimens: Uruguay: Artigas, 8 November 2013, L. Eggers et al. 838 (ICN).
Cypella magnicristata Deble, Phytotaxa 71: 63. 2012. Type: Brazil. Rio Grande do Sul: Quaraí, Jarau, 17 February 2010, L.P. Deble \& A.S. Oliveira-Deble 12816 (Holotype PACA [image!]).

Figs. 3D, 14.

Herb 30-40 cm high; basal leaves linear, $0.2-0.3 \mathrm{~cm}$ wide. Synflorescence of 4-5 pedunculate one-flowered rhipidia. Spathes lower valve $2.2-2.8 \mathrm{~cm}$ long, upper $4.2-5.5 \mathrm{~cm}$ long. Flowers moderate to strong orange, $60-70 \mathrm{~mm}$ diameter. Outer tepals pandurate, proximally concave, distally reflexed, densely covered by red-brown spots proximally; inner tepals cuneate, assurgent proximally, then incurved and abruptly reclinate distally, proximally densely striated purplish-brown, distally with white-cream central portion and dense elliptic orange area of elaiophores with a dark central line, laterally orange streaked with dark-purple and apically orange. Filaments free, 4.5-6.4 mm long; anthers 8-9 $\mathrm{mm}$ long; connective yellowish to beige, $1.2-1.8 \mathrm{~mm}$ wide; pollen ochraceous. Style whitish streaked with purplishbrown, 6-7 mm long; style arms yellowish sometimes with purplish-brown spots, 9-10 mm long, crests moderate to strong orange. Adaxial crests, 2, erect, falcate inwards, 5-7 $\mathrm{mm}$ long, abaxial crest lobed. Capsule obovoid.

Iconography: Deble et al. (2012c).
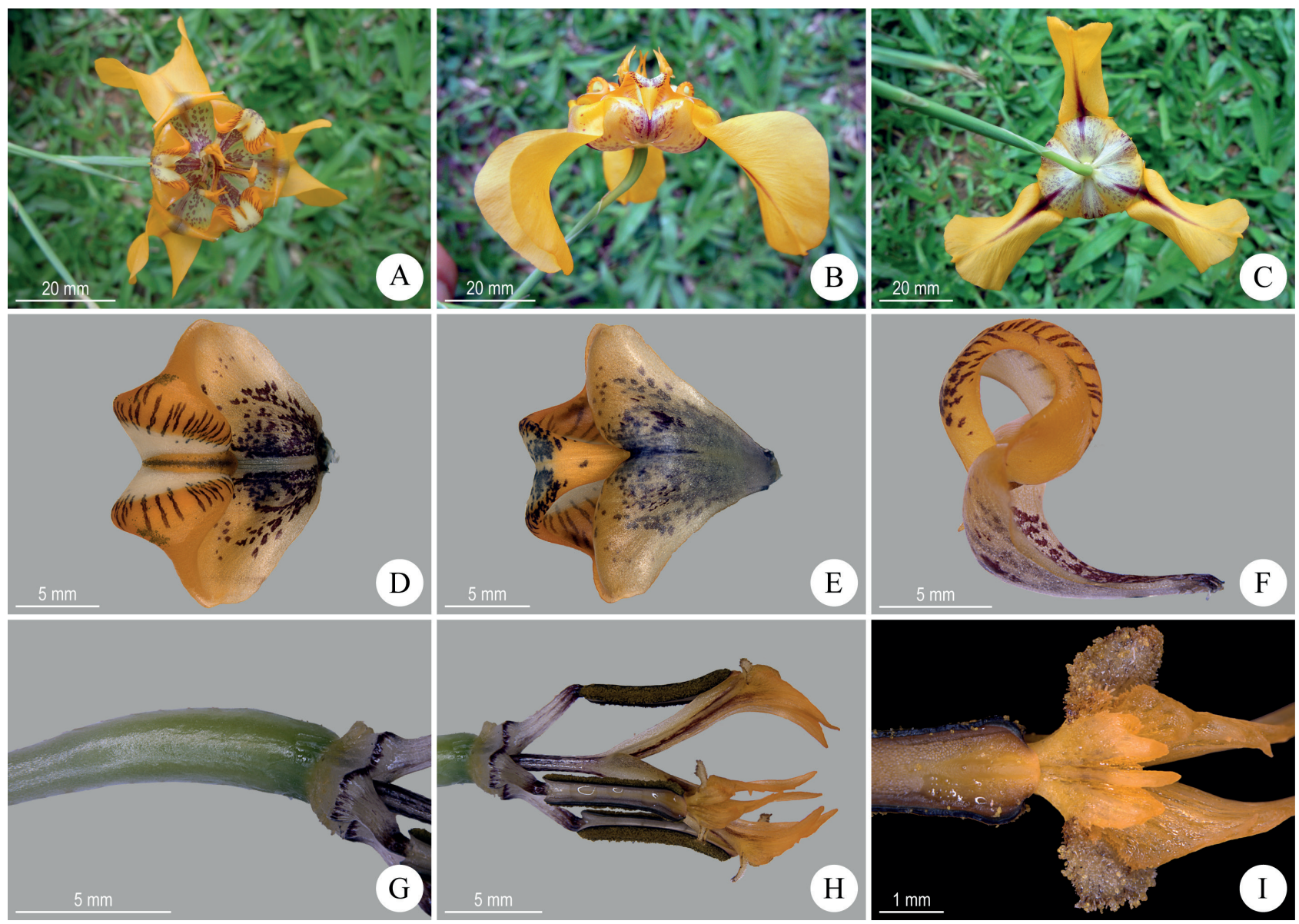

Figure 14. Cypella magnicristata. A-C. Flower. A. apical view B. lateral view C. basal view D-F. Inner tepal D. adaxial view E. abaxial view F. lateral view G. Ovary H. Stamens and style in lateral view I. Style crests and stigmatic replicatures. From: A.M. Aita 76 (ICN). 
Distribution, habitat, and phenology: Cypella magnicristata occurs in the south-western region of the state of Rio Grande do Sul, in the Pampa Biome. It grows in grasslands, in altitude records of about $150 \mathrm{~m}$ a.s.l. Flowering and fruiting individuals were collected from October to December, February and March (Deble et al. 2012c).

Conservation status: The species was categorized as Critically Endangered - CR, B1, B2a,b(iii), D by Deble et al. (2012c). Re-evaluation based additional collections qualified the species as Endangered - EN, B1, B2a,b(iii).

Notes: Cypella magnicristata presents the largest androgynoecium of the orange flowered species of Cypella (C. amplimaculata, C. fucata, C. herbertii subsp. herbertii), with filaments 5.5 to $6.4 \mathrm{~mm}$ long (vs. up to $3.6 \mathrm{~mm}$ ); anthers 8 to $9 \mathrm{~mm}$ long (vs. up to $6.8 \mathrm{~mm}$ ) and adaxial crests 6 to 7 mm long (vs. up to $5.3 \mathrm{~mm}$ ) (Fig. 3D vs. 3A-C).

Specimens examined: Brazil. Rio Grande do Sul: Santana do Livramento, 14 October 1974, M.L. Porto 1007 (ICN); Quaraí, 27 October 2011, A.M. Aita 76 (ICN); idem, 14 November 2013, E.M. Stiehl-Alves et al. 98 (ICN).

Cypella pusilla (Link \& Otto) Benth. \& Hook.f. ex B.D.Jacks. Index Kew. 1: 689. 1893.

三 Ferraria pusilla Link \& Otto, Icon. Pl. Select. 10: 125.
1828. Type: Brazil. Rio Grande do Sul: Porto Alegre, 1826, F. Sellow s.n. (Holotype presumed lost). Lectotype: Tab. 59 in Link \& Otto's Icones Plantarum Selectarum Horti Regii Botanici Berolinensis cum descriptionibus et colendi ratione 10: 125.1828 (designated by Pastori et al. 2018). Epitype: Brazil. Rio Grande do Sul: "Brésil Province de Rio-Grande", F. Sellow 2599 (designated by Deble \& Alves 2017a) (Epitype P!).

= Cypella gloriana Deble \& F.S.Alves, Darwiniana 3(2): 241. 2015. Type: Brazil. Rio Grande do Sul: São Vicente do Sul, Cerro da Glória, 25 October 2014, L.P. Deble et al. 15034 (Holotype SI [image!]; isotypes MVFA, not seen; PACA, not found).

Figs. 2H, 15.

Herb 8.7-29 cm high; basal leaves linear, 0.04-0.3 cm wide. Synflorescence simple or composed of 3-5 sessile to subsessile one-flowered rhipidia. Spathes lower valve 1-2 cm long, upper $1.5-2.8 \mathrm{~cm}$ long. Flowers pale to sulphur yellow or whitish, 19-41 mm diameter. Outer tepals pandurate, proximally concave, distally patent to reflexed, with scattered brown dots proximally; inner tepals clawed proximally, then erecto-patent, slightly incurved and abruptly reclinate distally, proximally with scattered brown dots, distally yellow with dense lanceolate yellow area of elaiophores, laterally spotted with purple-brown
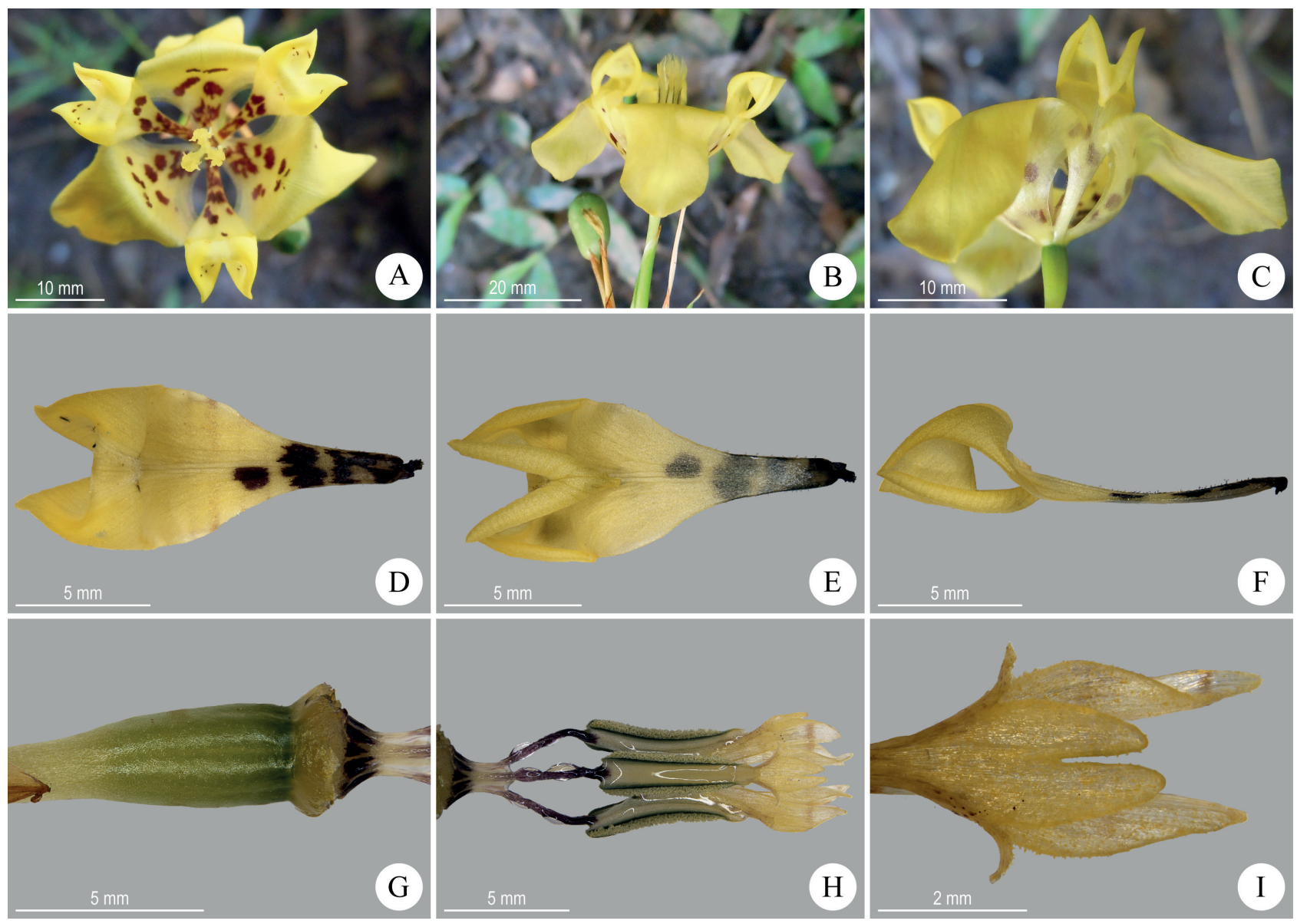

Figure 15. Cypella pusilla. A-C. Flower. A. apical view B. lateral view C. basal view D-F. Inner tepal D. adaxial view E. abaxial view F. lateral view G. Ovary H. Stamens and style in lateral view I. Style crests and stigmatic replicatures. From: L. Eggers et al. 818 (ICN). 
and apically yellow. Filaments free or connate basally for 1 $\mathrm{mm}, 3.8-6 \mathrm{~mm}$ long; anthers 4.1-6.1 mm long; connective whitish yellow, $0.3-1 \mathrm{~mm}$ wide; pollen whitish to greenishyellow. Style whitish to pale yellow, ca. 5-6 mm long; style arms whitish to pale yellow, 4.5-7.2 mm long, crests pale yellow to yellow, frequently striated purple or brown. Adaxial crests, 2, erect, falcate inwards, 2.1-4.6 mm long, abaxial crest ovate, entire to bilobed. Capsule obovoid.

Iconography: Deble et al. (2015a), as C. gloriana; Link \& Otto (1828); Pastori et al. (2018).

Distribution, habitat, and phenology: Cypella pusilla occurs in the central south and eastern regions of the state of Rio Grande do Sul, in the Atlantic Rainforest and Pampa Biomes. It grows in stony grasslands, and altitude records range from 107 to $431 \mathrm{~m}$ a.s.l. (Pastori et al. 2018). Flowering and fruiting individuals were collected from October to December and from March to May.

Conservation status: The species was recently reevaluated and qualified as Endangered - EN, B2a,b(iii) (Pastori et al. 2018), according to the IUCN Red List guidelines.

Notes: Cypella pusilla is a new combination for Ferraria pusilla, species described by Link \& Otto (1828) based on a plant obtained from bulb sent from Porto Alegre. Inclusion of this taxon in Cypella was proposed by Bentham \& Hooker (1883) and validated by Jackson (1893). In 2017, Deble \& Alves (2017a) indicated an epitype, and Pastori et al. (2018) designated the illustration in the original publication as lectotype. In the taxonomic treatment of Pastori et al. (2018), a recently new species named C. gloriana (Deble et al. 2015a) was synonymized to $C$. pusilla, based on results of phylogenetic analyses of plastid and nuclear markers, as well on multivariate analyses of 38 qualitative and quantitative morphological characters.

The species can be recognized by its characteristic sessile to subsessile rhipidia, which shape a fasciculiform synflorescence subtended by a bract up to $5 \mathrm{~cm}$ long, a distinctive synflorescence compared to the usual terminal synflorescences of the majority of the Cypella species.

Specimens examined: Illegible, s.d., J. Tweedie 166 (K); Brazil. Rio Grande do Sul: Alegrete, 6 March 2011, L.P. Deble et al. 12833 (ICN); Amaral Ferrador, 27 November 2014, T. Pastori \& O. Chauveau 174 (ICN); idem, 18 March 2015, T. Pastori \& O. Chauveau 186 (ICN); Bagé, 6 November 2014, T. Pastori et al. 156 (ICN); idem, 28 November 2014, T. Pastori \& O. Chauveau 184 (ICN); idem, 18 March 2015, T. Pastori \& O. Chauveau 188 (ICN); Caçapava do Sul, 23 May 1993, C. Schlindwein s.n. (MPUC 13547); idem, 17 April 2011, L.P. Deble et al. 13116 (ICN); idem, 12 November 2014 , T. Pastori et al. 170 (ICN); idem, 19 April 2014, L. Eggers \& O. Chauveau 914 (ICN); Canguçu, 2 May 2006, A.A. Schneider 1260 (ICN); Guaíba, 16 October 2008, L.P. Deble \& A.S. de Oliveira-Deble 10088 (ICN); Lavras do Sul, 20 November 2012, L. Eggers et al. 783 (ICN); idem, 27 October 2014, T. Pastori et al. 147 (ICN); idem, 19 March 2015, T. Pastori
\& O. Chauveau 190 (ICN); Pantano Grande, 14 May 2015, T. Pastori \& O. Chauveau 194 (ICN); Pinheiro Machado, 18 March 2015, T. Pastori \& O. Chauveau 187 (ICN); Porto Alegre, 12 April 1946, K. Emrich s.n. (PACA 33756); idem, 15 April 1944, K. Emrich s.n. (PACA 27470); idem, Morro Santa Teresa, 29 April 1949, B. Rambo s.n. (PACA 41292); idem, idem, 8 May 2013, C. Vogel-Ely et al. 389 (ICN); idem, Morro Santana, 2 April 2012, T.L.S. Alves 197 (ICN); idem, idem, 19 March 2013, L. Eggers et al. 818 (ICN); Santana da Boa Vista, 30 March 1975, A. Sehnem s.n. (PACA 86730); Santana do Livramento, 28 November 1993, C. Schlindwein et al. s.n. (MPUC 13548); idem, 7 December 2005, L.Y.S. Aona \& M.C. Machado 959 (UEC); São Francisco de Assis, 20 March 2015, T. Pastori \& O. Chauveau 193 (ICN); São Gabriel, 8 February 1996, R.R. Brooks et al. MS408 (MO); idem, 27 October 2014, T. Pastori et al. 148 (ICN); idem, 19 March 2015, T. Pastori \& O. Chauveau 192 (ICN); São Pedro do Sul, 08 December 2014, P.J.S. Silva Filho 2199 (ICN); São Vicente do Sul, 16 November 2010, L.P. Deble et al. 12744 (ICN); idem, 2 November 2012, L.P. Deble \& A.S. OliveiraDeble 12376 (SI); idem, 13 October 2014, T. Pastori et al. 119 (ICN); idem, Cerro da Glória, 25 October 2014, L.P. Deble et al. 15035 (SI); idem, 20 March 2015, T. Pastori \& O. Chauveau 193 (ICN); s.l., 1833, C. Gaudichaud 294 (P).

Cypella ravenniana Deble \& F.S. Alves, Phytotaxa 236(2): 109. 2015. Type: Argentina. Santo Tomé: Garruchos, Estancia San Juan Bautista, on stony rocky grassland, 22 December 2014, L.P. Deble \& F.S. Alves 15505 (Holotype SI [image!]; Isotypes CTES, not found; ICN, not found; MVFA, not seen).

Figs. 2I, 11C-D.

Herb 8-27 cm high; basal leaves linear, $0.2-0.4 \mathrm{~cm}$ wide. Synflorescence composed of 2-4 pedunculate one-flowered rhipidia. Spathes lowervalve 2.2-3.1 cmlong, upper $3.5-4.7 \mathrm{~cm}$ long. Flowers shiny yellow, 38-55 mm diameter. Outer tepals pandurate, proximally concave, distally reflexed, stained purple proximally; inner tepals clawed, then erecto-patent, incurved and abruptly reclinate distally, proximally stained purplish-brown, distally mostly yellow with yellow-cream central area of elaiophores, laterally streaked with reddishbrown and apically dull yellow. Filaments connate basally for 0.3-0.5 mm, 5.9-6.5 mm long; anthers 6.5-7.8 mm long; connective yellow, $0.9-1.2 \mathrm{~mm}$ wide, pollen greenish-yellow to ochraceous. Style yellow, $6.5-8 \mathrm{~mm}$ long; style arms yellow, 6-7 mm long, crests yellowish. Adaxial crests, 2, erect, falcate inwards, $4.5-7 \mathrm{~mm}$ long, abaxial crest deltate, lobed. Capsule obovoid.

Iconography: Deble et al. (2015b); Pastori et al. (2018).

Distribution, habitat, and phenology: Cypella ravenniana occurs in the western and north-western regions of the state of Rio Grande do Sul, in the Pampa Biome. The species also occurs in Argentina (Deble et al. 2015b). It grows in stony grasslands, in shallow soils, in altitude records of about $150 \mathrm{~m}$ a.s.l. Flowering and fruiting individuals were 
collected from November to January (Deble et al. 2015b), March and April.

Conservation status: The recently described species was classified as Vulnerable - VU, B1b(iii), c(iv), B2b(iii),c(iv) by Deble et al. (2015b). As the analysis of conservation status of the species was based on a larger amount of material than presented here, we accept the authors' categorization.

Notes: Cypella ravenniana can be recognized by the pandurate outer tepals, filiform filaments 5.9 to $6.5 \mathrm{~mm}$ long, anthers 6.5 to $7.8 \mathrm{~mm}$ long and adaxial crests $4.5-7$ mm long (Fig. 2I).

Specimens examined: Brazil. Rio Grande do Sul: São Borja, 7 November 2012, L. Eggers et al. 757 (ICN).

Additional examined specimens: Argentina: Corrientes, Ituzaingó, San Carlos, 11 December 2014, H.A. Keller \& M.M. Franco 12557 (CTES); Misiones, 23 March 1998, F.O. Zuloaga et al. 6572 (SI); Santo Tomé, 15 April 2014, H.A. Keller et al. 12073 (CTES).

Cypella rivularis Chauveau \& L.Eggers, Phytotaxa 174(1): 36. 2014. Type: Brazil. Rio Grande do Sul: Uruguaiana, BR 290, aproximadamente Km 645, 25 November 2013, L. Eggers et al. 869 (Holotype ICN!; Isotypes MBM!, P!).

Figs. 2J, 11E-F.

Herb 33.5-49 cm high; basal leaves linear, 0.4-0.7 cm wide. Synflorescence of 2-7 pedunculate one-flowered rhipidia. Spathes lower valve 1.5-2 cm long, upper 3.5-4.7 $\mathrm{cm}$ long. Flowers bright yellow, 50-58 mm diameter. Outer tepals pandurate, proximally concave, distally reclinate, with red-brown dots proximally and at the base of the petal blade; inner tepals shortly clawed to cuneate, then erecto-patent, incurved and abruptly reclinate distally, proximally dotted red-brown, distally bright yellow with dense lanceolate yellow area of elaiophores, laterally spotted red-brown and apically yellow. Filaments free or connate basally for 1-2 mm, 6.4-7.8 mm long; anthers 7.8-8.5 $\mathrm{mm}$ long; connective pale yellow, $0.9-1.2 \mathrm{~mm}$ wide; pollen yellow. Style whitish-yellow to pale yellow, 11-15.8 mm long; style arms pale yellow, 4-4.5 mm long, crests pale to whitish-yellow. Adaxial crests, 2, erect, falcate inwards, 5.9-6.8 mm long, abaxial elliptic, entire to slightly bilobed. Capsule obovoid-truncate.

Iconography: Chauveau et al. (2014).

Distribution, habitat, and phenology: Cypella rivularis occurs in the south-western region of the state of Rio Grande do Sul, in the Pampa Biome. It is found in aquatic vegetation, associated to lotic environments, growing along the banks and in the bed of narrow and stony grassland streams, in large and scattered populations. Altitude records range from 103 to $226 \mathrm{~m}$ a.s.l. (Chauveau et al. 2014). Flowering and fruiting occurs from November to December (cultivated material).

Conservation status: The species was categorized as Critically Endangered - CR, B2a,b(iii) by Chauveau et al. (2014). There are no additional collections or other elements to justify modification of threatened category, thus conservation status is maintained.

Notes: Cypella rivularis has characteristic bright yellow flowers with small red-brown dots at the outer and inner tepals and erect light yellow style crests. Cypella guttata occurs in similar habitat and also presents red spots at the tepals, however flowers are golden yellow and smaller (33-40 $\mathrm{mm}$ diameter), filaments are linear to triangular (Fig. $2 \mathrm{~F} v$ s. $2 \mathrm{~J}$ of $C$. rivularis) and pollen is grey.

Specimens examined: Brazil. Rio Grande do Sul: Alegrete, 25 November 2013, L. Eggers et al. 873 (ICN); idem, 26 November 2013, L. Eggers et al. 874 (ICN); Uruguaiana, 22 November 2012, L. Eggers et al. 800 (ICN); idem, 25 November 2013, L. Eggers et al. 872 (ICN).

\section{Dubious names}

Cypella exilis Ravenna, Nordic J. Bot. 1: 492. 1981. Lectotype: "Brasilia meridionalis, Montevideo", s.d., F. Sellow d.2077 (Lectotype B [image!]) (designated by Deble \& Alves 2017a).

See notes on C. amplimaculata.

Cypella pabstiana Ravenna, Wrightia 7(1): 18. 1981. Type: Brazil. Paraná: Guarapuava, "In campis siccis graminosis ad Entre Rios", 4 December 1969, P. Ravenna \& G. Hatschbach 1013 (Holotype Herb. Ravenna, not seen). Lectotype: Brazil. Paraná: Guarapuava, Entre Rios, 21 October 1969, G. Hatschbach 22552 (MBM!) (Lectotype, here designated).

The species was collected in dry grasslands and was considered allied to $C$. herbertii, differing by the lower size, narrower leaves, smaller floral organs and yellow flowers (Ravenna 1981b). Four unsuccessful field expeditions were carried out in the region of the type collection and proximities, and no other exsiccate with this name was retrieved in herbaria revision. We therefore treat it as a dubious species.

Nevertheless, a lectotype is here designated, by the choice of the only paratype cited at the original description.

The taxonomic treatment revealed that diversity of Cypella greatly decreases from Rio Grande do Sul (18 taxa), to Santa Catarina (4), Paraná (3) and São Paulo, Minas Gerais or Mato Grosso (1 sp.). Cypella crenata has the broadest Brazilian distribution, while various species are endemic of the Pampa Biome, in the state of Rio Grande do Sul. Ten taxa range exclusively in the Pampa Biome, two are exclusive of the Atlantic Rainforest Biome, six species occur in both, and one in the Cerrado Biome (C. crenata). Notwithstanding, the biogeographic unit of RPG is ascertained as the most important geographical area for the genus (Chauveau et al. 2014), since it includes the majority of the taxa presented here, as well as other species described for the Provinces of Entre Rios and Corrientes, Argentina. At least eight additional species occur in these areas, and some of them are not excluded to be recovered in Brazil, since collection sites are just at the border of both countries. 
Lastly, the studies carried out for the Brazilian Flora 2020 project and this manuscript retrieved records of Cypella in Central West and Northeastern Brazil. These collections are actually other taxa and most common misinterpretations are presented below:

Cypella coerulea Seub. is an incorrect spelling of Cypella caerulea Seub. ex Hook.f. The samples reported in online sources such as speciesLink (http://www.splink.org.br) are usually from Bahia and belong to species of Neomarica Sprague. For identification, the following references are recommended: Gil (2012), Lovo et al. (2018) and Gil \& Hall (2019).

Cypella glauca Seub. ex Klatt = Neomarica glauca $($ Seub . ex Klatt) Sprague.

Cypella gracilis $($ Herb.) Klatt $=$ Neomarica gracilis (Herb.) Sprague.

Cypella gracilis (Klatt) Baker is an illegitimate name, as presented in the notes of $C$. amplimaculata. Samples with this name are sometimes $C$. armosa, $C$. crenata, $C$. pusilla or the dubious C. exilis.

Cypella humilis Klatt is synonym of Neomarica humilis (Klatt) Capell., a species that occurs in Ceará, Paraíba and Pernambuco (Gil \& Hall 2019). However, samples at speciesLink are from Minas Gerais, Rio de Janeiro and São Paulo, indicating that identification checking is recommended.

Cypella linearis (Kunth) Baker is synonym of Larentia linearis (Kunth) Klatt. However, many samples identified as C. linearis from Northeastern Brazil belong to Alophia Herb.

Cypella longifolia Klatt (Cypella longifolia (Link \& Otto) Klatt) is synonym of Neomarica longifolia (Link \& Otto) Sprague. Samples with that identification were collected in the states of Alagoas and Paraíba. Neomarica longifolia is until now reported to Espírito Santo, Minas Gerais, Rio de Janeiro, Rio Grande do Norte and São Paulo (Gil \& Hall 2019). Determination checking is needed.

Cypella lutea Klatt $=$ Trimezia lutea $($ Klatt) Foster.

\section{Acknowledgements}

We thank the curators of Herbaria CGMS, CTES, PACA, RB and SI for information on species collections; MNHNHerbarium P for allowing access to types; J. Prado for nomenclatural advice; A.M. Aita and L. Dal Ri for images provided. We thank the Laboratório de Anatomia Vegetal of UFRGS for technical support; and PPG Botânica-UFRGS and CAPES for financial support - Financial Code 001. TTSC thanks CNPq for the grant [304506/2016-8] awarded. TP thanks PNPD/CAPES for the scholarship (\#88887.364124/2019-00).

\section{References}

Aita AM, Chauveau O, Souza-Chies TT, Eggers L. 2013. Two new species of Sisyrinchium (Iridaceae) from Subtropical Highland Grasslands of Southern Brazil. Phytotaxa 88: 9-18.
Alves TLS, Chauveau O, Eggers L, Souza-Chies TT. 2014. Species discrimination in Sisyrinchium (Iridaceae): Assessment of DNA barcodes in a taxonomically challenging genus. Molecular Ecology Resources 14: 324-335.

Andrade O, Bonilha CL, Overbeck GE, et al. 2019. Classification of South Brazilian grasslands: Implications for conservation. Applied Vegetation Science 22: 168-184.

Baker JG. 1877. Systema Iridacearum. Journal of the Linnean Society, Botany 16: 61-180.

Baker JG. 1892. Handbook of Irideae. London, George Bell \& Sons.

Barker C. 2019. World checklist of Iridaceae. Kew, The Board of Trustees of the Royal Botanic Gardens. http://wcsp.science.kew.org/10 Apr 2019.

Beentje H. 2016. The Kew plant glossary: an illustrated dictionary of plant terms. Richmond, Royal Botanic Gardens Kew.

Bentham G, Hooker JD. 1883. Cypella. In: Bentham G, Hooker JD. (eds.) Genera Plantarum 3(2). London, L. Reeve \& Co. p. 689-690.

BFG. 2015. Growing knowledge: an overview of Seed Plant diversity in Brazil. Rodriguésia 66: 1085-1113.

Chauveau O, Eggers L, Raquin C, et al. 2011. Evolution of oil-producing trichomes in Sisyrinchium (Iridaceae): insights for the first comprehensive phylogenetic analysis of the genus. Annals of Botany 107: 1287-1312.

Chauveau O, Eggers L, Souza-Chies TT, Nadot S. 2012. Oil-producing flowers with in the Iridoideae (Iridaceae): evolutionary trends in the flowers of the New World genera. Annals of Botany 110: 713-729.

Chauveau O, Pastori T, Souza-Chies TT, Eggers L. 2014. Overlooked diversity in Brazilian Cypella (Iridaceae, Iridoideae): four new taxa from the Río de la Plata grasslands. Phytotaxa 174: 25-42.

Chodat R, Hassler E. 1903. Plantae Hasslerianae soit Enumeration des Plantes Récoltées au Paraguay par le Dr. Emile Hassler d'Aarau (Suisse), de 1885 à 1902. Bulletin de l'Herbier Boissier 3: 1097-1127.

Coates DJ, Byrne M, Moritz C. 2018. Genetic diversity and conservation units : dealing with the species-population continuum in the age of genomics. Frontiers in Ecology and Evolution 6: 165. doi: 10.3389/ fevo.2018.00165

Deble LP. 2017. La identificacion de Cypella exilis Ravenna (Iridaceae). Balduinia 56: 27-34.

Deble LP, Alves FS. 2017a. Taxonomic novelties for the genus Cypella (Iridaceae): new species, synonymies and nomenclatural types. Kew Bulletin 72: 41. doi: 10.1007/S12225-017-9708-3

Deble LP, Alves FS. 2017b. The type of Cypella herbertii subsp. brevicristata Ravenna (Iridaceae: Tigridieae). Balduinia 56: 20-26.

Deble LP, Alves FS, Oliveira-Deble AS. 2015a. Three new species of the genus Cypella (Iridaceae, Tigridieae). Darwiniana 3: 235-253.

Deble LP, Alves FS, González A, Oliveira-Deble AS. 2015b. Three new species of Cypella (Iridaceae) from South America, and taxonomic delimitation of C. suffusa Ravenna. Phytotaxa 236: 101-120

Deble LP, Oliveira-Deble AS, Alves FS. 2012a. Cypella discolor Ravenna (Iridaceae: Tigridieae) é redescoberta nos campos do oeste e sudoeste do Rio Grande do Sul. In: Oliveira-Deble AS, Deble LP, Leão ALS. (orgs.) Bioma pampa: ambiente x sociedade. Bagé, Ediurcamp. p. 68-76.

Deble LP, Oliveira-Deble AS, Alves FS. 2012b. Novo registro de Cypella sect. Cypella (Iridaceae: Tigridieae) para o Brasil. Balduinia 35: 19-26.

Deble LP, Oliveira-Deble AS, Alves FS. 2012c. Two new species of Cypella (Iridaceae: Tigridieae) from Rio Grande do Sul, Brazil. Phytotaxa 71: 59-68.

Diniz-Filho JAF, Loyola RD, Raia P, Mooers AO, Bini LM. 2013. Darwinian shortfalls in biodiversity conservation. Trends in Ecology \& Evolution 28: 689-695.

Eggers L. 2008. A família Iridaceae no Parque Estadual de Itapuã, Viamão, Rio Grande do Sul, Brasil. Revista Brasileira de Biociências 6: 167-175.

Eggers L. 2010. Cypella. In: Forzza RC, Baumgratz JFA, Bicudo CEM, et al. (eds.) Catálogo de plantas e fungos do Brasil. Rio de Janeiro, Andrea Jakobsson, Instituto de Pesquisas Jardim Botânico do Rio de Janeiro. p. 1123.

Eggers L, Chukr N, Lovo J, Gil A. 2010. Iridaceae. In: Forzza RC, Baumgratz JFA, Bicudo CEM, et al. (eds.) Catálogo de Plantas e Fungos do Brasil. Rio de Janeiro, Andrea Jakobsson, Instituto de Pesquisas Jardim Botânico do Rio de Janeiro. p. 1122-1128. 
Flora do Brasil 2020 em construção. 2019. Cypella. Jardim Botânico do Rio de Janeiro. http://floradobrasil.jbrj.gov.br/reflora/floradobrasil/ FB8046. 7 May 2019.

Forzza RC, Baumgratz JFA, Bicudo CEM, et al. 2010. Catálogo de plantas e fungos do Brasil. Vol. 2. Rio de Janeiro, Andrea Jakobsson, Instituto de Pesquisas Jardim Botânico do Rio de Janeiro.

Freudenstein JV, Broe MB, Folk RA, Sinn BT. 2017. Biodiversity and the species concept-lineages are not enough. Systematic Biology 66: 644-656.

Gil ASB. 2012. Revisão taxonômica e estudos filogenéticos do gênero Neomarica s.l. (Iridaceae). PhD Thesis, Universidade Estadual de Campinas, Campinas.

Gil ASB, Hall CF. 2019. Neomarica. In: Flora do Brasil 2020 em construção. Jardim Botânico do Rio de Janeiro. http://floradobrasil.jbrj.gov.br/ reflora/floradobrasil/FB8052 06 May 2019.

Gil ASB, Bittrich V, Amaral MCE. 2014. Two new species of Neomarica Sprague (Trimezieae - Iridaceae) from Bahia State, Northeastern Brazil. Phytotaxa 164: 47-57.

Goldblatt P, Manning JC. 2008. The Iris Family: natural history and classification. Portland, Timber Press.

Herbert W. 1825. Tigridia Herberti. Curtis's Botanical Magazine 52: plate 2599.

IBGE - Instituto Brasileiro de Geografia e Estatística. 2004. Biomas. https://www.ibge.gov.br/geociencias/cartas-e-mapas/informacoesambientais/15842-biomas.html?=\&t=downloads. 12 Jul. 2019.

Iganci JRV, Heiden G, Miotto ST, Pennington RT. 2011. Campos de Cima da Serra: the Brazilian Subtropical Highland Grasslands show an unexpected level of plant endemism. Botanical Journal of the Linnean Society 167: 378-393.

Inácio CD, Chauveau O, Souza-Chies TT, Sauquet H, Eggers L. 2017. An updated phylogeny and infrageneric classification of the genus Sisyrinchium (Iridaceae): challenges of molecular and morphological evidence. Taxon 66: 1317-1348

Inácio CD, Chauveau O, Eggers L. 2018. Three new species of Sisyrinchium from Campos of South America. Phytotaxa 361: 198-210.

IUCN. 2017. Guidelines for using the IUCN Red List Categories and Criteria, version 13. http://www.iucnredlist.org/documents/RedListGuidelines. pdf. 10 Apr. 2019.

Jackson BD. 1893. Cypella. Index Kewensis 1(2): 689.

Klatt FW. 1861-62. Monographia generis Sisyrinchium. Linnaea 31: 63-100.

Klatt FW. 1871. Iridaceae ("Irideae") In: Martius CFP. Flora Brasiliensis 3(1): 510-546, tab. 64-71.

Lawrence GHM. 1957. Cypella Herbertii. Bayleia 5(1): 61.

Lindley J. 1826 (1825). Moraea herberti. The Botanical Register 11: plate 949.

Link JHF, Otto CF. 1828. Ferraria pusilla. Icones Plantarum Selectarum Horti Regii Botanici Berolinensis 10, p.125, t.59.

Lovo J, Mello-Silva R. 2011. Trimezia campanula, a new species of Trimezieae (Iridaceae) from Brazil. Brittonia 63: 457-460.

Lovo J, Winkworth RC, Mello-Silva R. 2012. New insights into Trimezieae (Iridaceae) phylogeny: what do molecular data tell us? Annals of Botany 110: 689-702.

Lovo J, Winkworth RC, Gil ASB, Amaral MCE, Bittrich V, Mello-Silva R. 2018. A revised genus-level taxonomy for Trimezieae (Iridaceae) based on expanded molecular and morphological analyses. Taxon 67: 503-520.
Maund B. 1840. Cypella Herberti. The Botanist 4: plate 199.

NYBG - New York Botanical Garden. 2019. Index Herbariorum. http:// sweetgum.nybg.org/science/ih/. 21 Apr. 2019.

Oliveira PN, Gil ASB, Giulietti AM, Oliveira RP, Amaral MCE. 2016. Neomarica castaneomaculata and N. involuta (Iridaceae): two new endemic species from the Atlantic Forest, Brazil. Phytotaxa 286: 89-98.

Overbeck GE, Müller SC, Fidelis A, et al. 2007. Brazil's neglected biome: The South Brazilian Campos. Perspectives in Plant Ecology, Evolution and Systematics 9: 101-116.

Pastori T, Eggers L, Souza-Chies TT, Chauveau O. 2018. Iterative taxonomy based on morphological and molecular evidence to estimate species boundaries: a case study in Cypella (Iridaceae: Iridoideae). Plant Systematics and Evolution 304: 1117-1140.

Pimm SL, Jenkins CN, Abell R, et al. 2014. The biodiversity of species and their rates of extinction, distribution, and protection. Science 344 : 1246752. doi: 10.1126/science. 1246752

Plachon JE. 1849. Cypella herberti. Flore des Serres et des Jardins de l'Europe 5: 537.

Ravenna P. 1965. Notas sobre Iridaceae II. Boletin de la Sociedad Argentina de Botanica 10: 311-322.

Ravenna P. 1968. Iridaceae. In: Cabrera AL. (ed.) Flora de la Província de Buenos Aires. Buenos Aires, INTA. p. 539-565.

Ravenna P. 1981a. A submerged new species of Cypella (Iridaceae), and a new section for the genus (s.str.). Nordic Journal of Botany 1: 489-492.

Ravenna P. 1981b. Eight new species and two new subspecies of Cypella (Iridaceae). Wrightia 7: 13-22.

Ravenna P. 2000. Cypella laxa (Iridaceae), reported in the flora Paraguay. Onira 4: 1-2

Ravenna P. 2003. Flora do Paraguay - Iridaceae. Botanica Australis 4: 1-60.

Ravenna P. 2005. New species of South American Bulbous Iridaceae. Onira 10: 39-45.

Ravenna P. 2009. A survey in the genus Cypella and its allies (Iridaceae). Onira 12: 1-11.

Rio Grande do Sul. 2014. Decreto n. 52.109, de 01 de dezembro de 2014. Declara as espécies da flora native ameaçadas de extinção do Rio Grande do Sul. Diário Oficial Estado Rio Grande do Sul, Porto Alegre, RS, 02 dec. 2014.

Roitman GG, Castillo A. 2003. Novedades en el género Cypella (Iridaceae). Boletin de la Sociedad Argentina de Botanica 38: 337-339.

Roitman GG, Castillo A. 2007. Nuevas combinações en Iridaceae. Darwiniana 45: 236-241.

Roitman GG, Castillo A, Maza I, Goldblatt P. 2008. Iridaceae. In: Zuloaga FO, Morrone O, Belgrano MJ. (orgs.) Catálogo de las plantas vasculares del Cono Sur (Argentina, Sur de Brasil, Chile, Paraguay y Uruguay). St. Louis, Missouri Botanical Garden. p. 423-453.

Stiehl-Alves EM, Kaltchuk-Santos E, Eggers L, Souza-Chies TT. 2017. Using a population genetics approach for a preliminary investigation concerning species boundaries in Herbetia (Iridaceae). International Journal of Plant Sciences 178: 439-449.

Sweet R. 1831. Cypella herberti. British Flower Garden ser. 2, plate 33.

Vellozo JMC. 1831 (1827). Florae Fluminensis Icones 9: tab. 67. Parisiis [Paris]: ex off. lithogr. Senefelder. http://dx.doi.org/10.5962/bhl. title. 890

Wilson EO. 2017. Biodiversity research requires more boots on the ground. Nature Ecology \& Evolution 1: 1590-1591. 


\section{Erratum - Correction in Authorship}

In the article "A taxonomic synopsis of Cypella (Iridaceae) in Brazil", with DOI number: 10.1590/0102-33062019abb0165, published in the journal Acta Botanica Brasilica 33 (4): 741-769, on pages 741 and 768.

\section{In page 741 , where it reads:}

Lilian Eggers ${ }^{1,2 *}$ http://orcid.org/0000-0002-5187-1493

Rafaella Marchioretto ${ }^{1}$ http://orcid.org/0000-0002-0038-0264

Tatiana T. Souza-Chies ${ }^{1,2}$ http://orcid.org/0000-0002-1818-8748

Olivier Chauveau ${ }^{2,3}$ http://orcid.org/0000-0002-3357-6271

${ }^{1}$ Departamento de Botânica, Universidade Federal do Rio Grande do Sul, 91501-970, Porto Alegre, RS, Brazil

${ }^{2}$ Programa de Pós-Graduação em Botânica, Universidade Federal do Rio Grande do Sul, 91501-970, Porto Alegre, RS, Brazil

${ }^{3}$ Ecologie Systématique et Evolution, Univ. Paris-Sud, CNRS, AgroParisTech, Université Paris-Saclay, 91405, Orsay, França

\section{It should be read as:}

Lilian Eggers ${ }^{1,2 *}$ http://orcid.org/0000-0002-5187-1493

Rafaella Marchioretto ${ }^{1}$ http://orcid.org/0000-0002-0038-0264

Tatiana T. Souza-Chies ${ }^{1,2}$ http://orcid.org/0000-0002-1818-8748

Tamara Pastori ${ }^{2}$ http://orcid.org/0000-0002-2477-0275

Olivier Chauveau ${ }^{2,3}$ http://orcid.org/0000-0002-3357-6271

${ }^{1}$ Departamento de Botânica, Universidade Federal do Rio Grande do Sul, 91501-970, Porto Alegre, RS, Brazil

2 Programa de Pós-Graduação em Botânica, Universidade Federal do Rio Grande do Sul, 91501-970, Porto Alegre, RS, Brazil

${ }^{3}$ Ecologie Systématique et Evolution, Univ. Paris-Sud, CNRS, AgroParisTech, Université Paris-Saclay, 91405, Orsay, França

\section{In page 768 , where it reads:}

"We thank the curators of Herbaria CGMS, CTES, PACA, RB and SI for information on species collections, and MNHN-Herbarium P for allow access to types. We thank J. Prado for nomenclatural advice; A.M. Aita, L. Dal Ri and T. Pastori for images provided. We thank PPG Botânica-UFRGS and Coordenação de Aperfeiçoamento de Pessoal de Nível Superior (CAPES) for financial support - Finance Code 001. TTSC thanks Conselho Nacional de Desenvolvimento Científico e Tecnológico (CNPq) for the grant [304506/2016-8] awarded."

\section{It should be read as:}

"We thank the curators of Herbaria CGMS, CTES, PACA, RB and SI for information on species collections; MNHN-Herbarium P for allowing access to types; J. Prado for nomenclatural advice; A.M. Aita and L. Dal Ri for images provided. We thank the Laboratório de Anatomia Vegetal of UFRGS for technical support; and PPG Botânica-UFRGS and CAPES for financial support - Financial Code 001. TTSC thanks CNPq for the grant [304506/2016-8] awarded. TP thanks PNPD/CAPES for the scholarship (\#88887.364124/2019-00)." 